\title{
Multiple Large Shareholders, Control Contests, and Implied Cost of Equity*
}

\author{
Najah Attig \\ Sobey School of Business, Saint Mary's University, Halifax, NS A1B 3X5, Canada \\ Najah.Attig@smu.ca \\ Omrane Guedhami \\ Moore School of Business, University of South Carolina, Columbia, SC 29208, USA \\ Omrane.Guedhami@moore.sc.edu
}

\begin{abstract}
Dev Mishra
Edwards School of Business, University of Saskatchewan, Saskatoon, SK S7N 5A7, Canada Mishra@edwards.usask.ca
\end{abstract}

\begin{abstract}
In this paper, we examine whether the presence of multiple large shareholders alleviates firm's agency costs and information asymmetry embedded in ultimate ownership structures. We extend extant corporate governance research by addressing the effects of multiple large shareholders on firm's cost of equity capital-a proxy for firm's information quality. Using data for 1,165 listed corporations from 8 East Asian and 13 Western European countries, we find evidence that the implied cost of equity decreases in the presence of large shareholders beyond the controlling owner. We also find that the voting rights, the relative voting size (vis-à-vis the first largest shareholder) and the number of blockholders reduces firm's cost of equity. Interestingly, we uncover that the presence of multiple controlling shareholders with comparable voting power lowers firm's cost of equity. We also find that the identity of the second largest shareholder is important in determining the risk of corporate expropriation in family-controlled firms. Our regional analysis reveals that, mainly in East Asian firms, multiple large shareholders structures exert an internal governance role in curbing private benefits and reducing information asymmetry evident in cost of equity financing, perhaps to sidestep deficiencies in the external institutional environment.
\end{abstract}

May 2008

JEL classification: G32; G34

Key words: corporate governance, multiple large shareholders, cost of equity

\footnotetext{
* We thank Narjess Boubakri, Sadok El Ghoul, and Oumar Sy for insightful comments. We appreciate generous financial support from the Social Sciences and Humanities Research Council of Canada and outstanding research assistance from Walid Saffar.
} 


\title{
Multiple Large Shareholders, Control Contests, and Implied Cost of Equity
}

\begin{abstract}
In this paper, we examine whether the presence of multiple large shareholders alleviates firm's agency costs and information asymmetry embedded in ultimate ownership structures. We extend extant corporate governance research by addressing the effects of multiple large shareholders on firm's cost of equity capital-a proxy for firm's information quality. Using data for 1,165 listed corporations from 8 East Asian and 13 Western European countries, we find evidence that the implied cost of equity decreases in the presence of large shareholders beyond the controlling owner. We also find that the voting rights, the relative voting size (vis-à-vis the first largest shareholder) and the number of blockholders reduces firm's cost of equity. Interestingly, we uncover that the presence of multiple controlling shareholders with comparable voting power lowers firm's cost of equity. We also find that the identity of the second largest shareholder is important in determining the risk of corporate expropriation in family-controlled firms. Our regional analysis reveals that, mainly in East Asian firms, multiple large shareholders structures exert an internal governance role in curbing private benefits and reducing information asymmetry evident in cost of equity financing, perhaps to sidestep deficiencies in the external institutional environment.
\end{abstract}

May 2008

JEL classification: G32; G34

Key words: corporate governance, multiple large shareholders, cost of equity 


\section{Introduction}

A long stream of literature has sought to understand the economic effects of the separation between ownership and voting rights of the controlling shareholder. Empirical evidence suggests that minority investors of firms in which the controlling shareholder holds control rights in excess of his/her commensurate capital investment are vulnerable to expropriation problems. ${ }^{1}$ However, the bulk of extant studies have been limited by an implicit assumption that overlooks the potential role of other large shareholders in curbing expropriation. With the exception of Laeven and Levine (2007) and Maury and Pajuste (2005), most of the empirical studies focus little, if any, attention on the role of multiple large shareholders (MLS, hereafter) in corporate governance. Arguably, the neglect of the potential monitoring benefits of blockholders, beyond the largest controlling shareholder, reflects the assumption that the former represent a homogenous group of uninvolved stakeholders, with weak incentives and little power to engage in monitoring activities. Yet, La Porta et al. (1999), Claessens et al. (2000) and Faccio and Lang (2002) all document numerous instances of multiple large blockholders across the globe.

Although recent theoretical developments have expanded the discussion of firm's agency costs to address the potential economic effects of the existence of large blockholders, beyond the controlling shareholder, they do not provide unequivocal evidence of the governance role of MLS. Indeed, investors may perceive the presence of MLS with efficient monitoring because large shareholders can bring valuable internal monitoring either by forming coalitions with large equity stakes or by competing for corporate control (e.g., Bennedsen and Wolfenzon (2000), Bloch and Hege (2001)). Alternatively, under the alignment-of-interests hypothesis, MLS can present an opportunistic structure for coercive voting, where blockholders would find it mutually valuable to collude to extract divisible private benefits of control (e.g.,

\footnotetext{
${ }^{1}$ La Porta et al. (1999) suggest that agency costs and asymmetric information problems in publicly traded firms are mainly driven by the separation between control and ownership rights (i.e., excess control) of the controlling shareholder. Empirical studies document that excess control engenders value discount (Claessens et al. (2002), La Porta et al. (2002)), lower informativeness of firm's reported earnings (Fan and Wong (2002)), higher earnings management (Haw et al. (2004)), higher liquidity costs and asymmetric information (Attig et al. (2006)), and influences the quality of financial reporting (Fan and Wong (2005), El Ghoul et al. (2007)).
} 
Winton (1993), Zwiebel (1995), Kahn and Winton (1998)). ${ }^{2}$ These divergent perspectives imply that whether or not MLS serve a monitoring role in mitigating the agency problems that beset concentrated control remains an open question. In addition, whether or not the efficient monitoring hypothesis of MLS outweighs any associated negative effects is a priori unclear.

We contribute to this timely, but unresolved, debate by empirically examining the effect of MLS on firms' cost of equity capital. We advance the related literature in many aspects. We provide the first cross-country evidence on the effects of MLS on the cost of equity capital. By doing so, we complement recent evidence by Laeven and Levine (2007), who examine the effects of MLS on corporate value. We depart from their focus on firms from strong protective legal environments in Western Europe by including firms from less protective countries in East Asia, where information problems are more severe at both the firm- and country-level. This improved variation across legal environments enables us to better understand the informational role of MLS. Second, also in contrast to Laeven and Levine (2007), who focus on the distribution of ownership rights between the first and second largest shareholders, we concentrate on the distribution of ultimate control rights because it is our contention that control is more relevant in determining the outcome of conflicts of interest. ${ }^{3}$ Third, we depart from Laeven and Levine (2007), who focus on the interaction between the two largest blockholders, by controlling for up to the fifth largest shareholders. By doing so, we are able to assess the governance effects of the number, voting size, and voting distribution among the five controlling shareholders. Fourth, because most of the recent empirical evidence suggests that agency problems around the globe rest in the misalignment between the control and ownership stakes of ultimate owners, we assess the impact of MLS in shaping the outcome of the largest shareholder's excess control. Our study complements also Guedhami and Mishra (2008), who document a positive relation between the cost of equity capital and the largest shareholder's excess control, by showing that MLS can play an important monitoring role by moderating the governance and information

\footnotetext{
2 Other research considers both views of the role of MLS in corporate governance. For instance, Gomes and Novaes (2005) argue that bargaining problems between large shareholders have the potential to either obstruct projects harming minority shareholders or result in corporate paralysis if profitable projects are denied. By solving this tradeoff, they find that MLS are efficient in situations where the likelihood of minority shareholders' expropriation is high and financing requirements are large.

${ }^{3}$ Considering both dimensions (i.e., control and ownership), after controlling for multicollinearity, could be more insightful; however, ultimate ownership rights were not available for East Asian firms.
} 
problems stemming from excess control. Last but not least, by examining the effects of MLS on the firm's discount rate rather than valuation, we identify a channel through which MLS affect valuation. In addition to being critical for a firm's investing and financing decisions, our interest in the cost of equity is motivated by its utility in capturing firm's information quality. ${ }^{4}$

Our interest in firms' financing costs reflects arguments in the literature that costs of external finance are driven by the extent of firm's agency and information problems. Indeed, extant corporate governance research suggests that concentrated control is widespread and can be responsible for serious information problems, which can result in increased costs to firms since financing becomes more expensive (La Porta et al. $(1997,2002))$. As explained by Dyck and Zingales (2004, p. 52), the potential extraction of private benefits by controlling shareholders "reduces what minority shareholders are willing to pay for shares, lowering the value of all companies where such behavior represents a real possibility. And by raising the cost of finance, it limits the ability of such firms to fund attractive investment projects." Undeniably, recent accounting and finance literature-demonstrating a renewed interest in the determinants of cost of capital-has documented a significant association between the cost of equity capital and information quality. This relationship is particularly evident in the theoretical work of Easley and O'Hara (2004) and Hughes et al. (2006), who demonstrate that firm's information quality (e.g., asymmetric information) leads to high cost of capital. Available empirical evidence lends support to this relationship. For instance, Botosan (1997) finds that greater disclosure is associated with a lower cost of equity capital for firms. Similarly, Sengupta (1998) and Francis et al. (2005) show that enhanced financial information quality (e.g., more transparent earnings, more independent audit committees, and lower abnormal accruals) is associated with lower cost of equity capital. Lambert et al. (2007) show also that information risk affects firm's beta and agency costs which, in turn, influences cost of equity capital. In contemporaneous crosscountry research, Hail and Leuz (2006) show that legal institutions and securities regulations explain cross-country differences in the cost of equity capital. We extend Hail and Leuz's (2006)

\footnotetext{
${ }^{4}$ Hail and Leuz (2006, p. 486) rely on similar arguments to motivate the investigation of the impact of legal institutions and securities regulations on the cost of equity capital: "It is possible that the valuation effects primarily reflect differences in the level of expropriation and firms' growth opportunities. But effective legal institutions may also reduce the risk premium demanded by investors, and hence firms' cost of capital."
} 
cross-country findings by showing that firm-level internal governance, manifest in MLS, explains differences in firms' cost of equity capital.

Our paper complements and extends this line of studies to include the impact of MLS, a proxy for firm's internal governance, on cost of equity capital for a panel of 1,165 listed corporations from 8 East Asian and 13 Western European countries. In estimating firms' cost of equity capital, we employ four variations of accounting-based residual income valuation models (Ohlson (1995), Feltham and Ohlson (1995)). 5 After controlling for other potential determinants of the cost of capital, our findings for the full sample suggest that the presence, the number and the control size of multiple large blockholders-beyond the largest shareholder-are associated with significantly lower cost of equity estimates, lending support to the efficient-monitoring role of MLS. Our results are robust to including an extensive set of control variables. Economically, our estimates indicate that increasing the ownership stake of the second largest shareholder from the first to the third quartile in our data results in firms' cost of equity capital decreasing by 25 basis points.

We also find that uneven distribution of control rights among large shareholders reduces the effectiveness of MLS monitoring. Stated differently, the presence of multiple controlling shareholders with comparable voting power mitigates firm's agency costs and lowers firm's cost of equity capital; plausibly because a high risk of control contestability (of the largest controlling shareholder) is likely to enhance firm's information quality and thus lower cost of equity capital. Additional tests investigating whether ownership identity matters reveal that when the two largest shareholders are families, the information risk is high and so too is the cost of equity capital. In contrast, the presence of the state as the second largest shareholder in family-controlled firms seems to moderate firm's agency costs and lowers its cost of equity. Additional analysis that involves separately examining firms from East Asia and Western Europe suggest that the governance role of MLS is more valuable in East Asia, where agency

\footnotetext{
${ }^{5}$ These models imply the cost of equity capital ex-ante (as a discount rate) based on analysts' forecasts of future earnings, price, book value and dividend per share. Recent research exploits these models to estimate firms' cost of equity capital (e.g., Gode and Mohanram (2003), Francis et al. (2004), Botosan and Plumlee (2005), Dhaliwal et al. (2005, 2006), Hail and Leuz (2006)) given arguments in the asset pricing literature that the realized return is a noisy and debatably biased proxy for the cost of equity capital (e.g., Elton (1999), Botosan (1997), Fama and French $(1997,2004))$.
} 
problems imbedded in ultimate ownership structures are more severe and the legal environment is weak.

Overall, our findings are insightful as they suggest that the discount rate is an important channel through which investors value the monitoring role of MLS in limiting the diversion of firm's resources for private benefits. However, they should still be interpreted cautiously because despite the battery of robustness tests to which we subject our findings, we were not able to control for the common causality bias in this line of research. For instance, Laeven and Levine (2007, p. 6) state that "one concern is that our results are driven by an omitted variable". We borrow the same argument regarding the difficulty in proving causality because of "the absence of time-series data on firm ownership across Europe [and Asia] and hence the inability to use firm-fixed effects or dynamic panel procedures".

The remainder of the paper is organized in four sections. Section 2 outlines the sample, defines the cost of equity estimates, and reports summary statistics on the regression variables. Section 3 covers the empirical evidence and the sensitivity analysis. Section 4 concludes.

\section{Data and Research Design}

\subsection{Sample Selection and Ownership Data}

To investigate the impact of MLS on the cost of equity capital, we first compile ownership data for a sample of firms from 8 East Asian economies (Hong Kong, Indonesia, Korea, Malaysia, Philippines, Singapore, Taiwan, and Thailand) used by Claessens et al. (2000) and 13 from Western Europe (Austria, Belgium, Finland, France, Germany, Ireland, Italy, Norway, Portugal, Spain, Sweden, Switzerland, and the U.K.) used by Faccio and Lang (2002). ${ }^{6}$ These studies provide the voting rights of the ultimate owner estimated in 1996 for East Asia and between 1996 and 1999 for Western Europe. Essential to our analysis, they also provide identity and voting rights of up to the four largest controlling shareholders, beyond the ultimate owner. We then hand-match this sample with Worldscope and I/B/E/S databases, which we use

\footnotetext{
${ }^{6}$ We exclude Japan from our sample as Japanese firms are required by law to provide future earnings forecasts on their own firm. Although the forecasts provided by firms are not included in estimating consensus forecasts (that we use in this study), the forecasts given by analysts are likely to be affected by firms' own forecasts.
} 
to collect financial information, and analysts' earnings forecasts and pricing information, respectively, for the period 1995-1997. We apply the following standard screening criteria. We require that the sample firms have (i) non-negative average earnings forecasts for the first and second year; (ii) either third-year average earnings forecasts or long-term growth rate; (iii) price per share available for the statistics release date; (iv) forecasts recorded by at least two analysts; (v) non-negative book value in Worldscope. Next, we implement the cost of equity models as outlined in Appendix A.1 and further exclude observations for which the cost of equity estimates are undefined (OJ model), do not converge (ES, CT, and GLS models), are outside the $1^{\text {st }}$ and 99th percentiles in the CT model - the model with the most dispersed estimates - and have earnings growth forecasts over 200\%.7 Although I/B/E/S releases earnings forecasts each month, earnings forecast statistics that meet the above requirements are not always available for some firms in every month. Therefore, we choose the first available earnings forecast that was made farthest back from the forecast period end date. ${ }^{8}$ As a final screen, we restrict our sample to firms in which at least one shareholder has total voting rights of $10 \%$ or more. ${ }^{9}$ Our final sample consists of 1,165 firms and 2,518 firm-year observations.

Although not a particular focus of this study, we control for excess control (Excess1) of the largest ultimate owner, defined as the difference between voting rights and cash flows rights, given the evidence in Claessens et al. (2002) that excess control affects firm valuation. We recall that the primary objective of this study is to empirically investigate whether MLS have a monitoring role over the largest owner that influences firms' governance and information

7 The evidence in Easton and Monahan (2005) suggests that the reliability of the cost of equity estimates of the residual valuation models decreases with larger and sluggish growth forecasts.

${ }^{8}$ For example, for the forecasts made for the year-end (e.g., December 1996) and recorded four times in a particular year (e.g., February, April, May, and August), we use the forecast made in February to estimate the implied cost of equity capital for that year in the models described in Appendix A.1. Some of the firmyears have earnings forecasts that are not exactly one year apart from the earnings forecast end date. In addition, when we implement our models to search the implied cost of equity that makes the estimated present value of future residual earnings equal to current price, the actual price observed on the forecast release date for such firm-years is simultaneously discounted to the beginning of the period. For example, for a forecast made for December 1995 and a statistics release date of March 1995, we discount the price observed in March 1995 back to January 1995.

${ }^{9}$ The $10 \%$ cutoff is used extensively in the literature as it is sufficient to exert control in a majority of cases (La Porta et al. $(1999,2002))$. 
problems and cost of equity capital. ${ }^{10}$ We mainly focus on MLS-related variables that capture the control contestability of the ultimate controlling owner. We start by examining the governance role of the second largest shareholder by specifying a dummy variable (Presence2) that takes the value of 1 if the firm has at least two large shareholders with more than $10 \%$ voting rights, and 0 otherwise. To the extent that MLS is perceived as an alternative internal governance device, we expect a negative relation between the presence of a second large shareholder and the firm's cost of equity. We also control for the size of the voting rights of the second largest shareholder (Cont2). Then we use the ratio of the voting rights of the second largest shareholder (Cont2) to the voting rights of the controlling owner (Cont1); we label this proxy Voting $2 \% 1$. This ratio measures the relative power of the second largest shareholder visà-vis the first largest shareholder, with higher values implying comparable sizes between the controlling stakes of the two largest shareholders. Under the efficient-monitoring assumption we predict negative relations between these two proxies (i.e., Cont2 and Voting2\%1) and the cost of equity capital.

While we initially start by isolating the shareholding attributes of the second largest shareholder, we extend our analysis to include other large shareholders. More specifically, we control for the number of MLS beyond the controlling owner (Nowners2345). This is a proxy for MLS composition that enables us to disentangle the bargaining effect (Gomes and Novaes (2005)) from the coalition formation effect (Bennedsen and Wolfenzon (2000)) of MLS. The coalition formation hypothesis predicts that, all else equal, the larger the number of shareholders, the more likely the winning coalition will hold a small equity stake, thereby externalizing more of the outcome of its actions and resulting in an increase in firm's agency costs. In addition, potential disagreement (and miscommunication) among a large number of blockholders implies weaker monitoring by MLS which, in turn, may increase the cost of equity capital. Taken together these two arguments suggest a positive relationship between Nowners 2345 and cost of equity capital. Alternatively, the bargaining-effects hypothesis suggests that disagreement among a large number of shareholders implies that projects likely to dilute minority shareholders' interests will be rejected, thereby translating into improved governance. We

\footnotetext{
10 Although the direction of the relations between the MLS variables and the cost of equity capital is unclear a priori, for expositional convenience we largely predict that the contestability of the ultimate owner's power will mitigate information asymmetry problems and lower the cost of equity capital.
} 
hypothesize that, under the bargaining-effects assumption, the presence of a large number of blockholders will improve the quality of information conveyed to the market; thus a negative effect of Nowners 2345 on cost of equity capital is expected. Since it is unclear which hypothesis, $a$ priori, should dominate, the relationship between the cost of equity and the number of large shareholders is an empirical issue.

We consider the monitoring role of a coalition of the largest four blockholders (beyond the first largest shareholder). We use similar measures to those constructed when addressing the monitoring role of the second largest shareholder, Cont2345 (which is equal to the sum of the voting rights of the second, third, fourth, and fifth largest shareholders), and Voting $2345 \% 1$ (which is the ratio of Cont2345 to Cont1). Equally important, we consider a proxy for the dispersion of control stakes among the five largest blockholders (Hi_Differences), measured as the sum of the square of the differences between the control stakes of the five largest shareholders (i.e., $\left.(\text { Cont1-Cont } 2)^{2}+(\text { Cont2-Cont } 3)^{2}+(\text { Cont3-Cont4 })^{2}+(\text { Cont4-Cont5 })^{2}\right)$. Given that higher values of Hi_Differences imply lower contestability of the power of the controlling owner, we expect a positive relationship between this proxy and cost of equity capital.

We use a proxy to measure the power of the small shareholders (i.e., the ocean). To this end, we rely on the framework of Milnor and Shapley (1978) to estimate the Shapley value of the ocean's votes, which is the probability that those votes are pivotal in a control contest. We then specify Shapley5 as the Shapley value of votes held by small shareholders divided by their fraction of votes (Zingales (1994)). We use the five largest ultimate control stakes to compute the Shapley value. A negative relation between Shapley5 and cost of equity capital is an indication of the monitoring effect of the ocean and the value of its votes in potential control contests.

Finally, we investigate whether the type of MLS-families, the state, or widely-held financial institutions (banks) - shapes their agency properties. Given the extensive research examining family ownership, we particularly focus on family firms, and conjecture that the likelihood of sharing private benefits of control is higher between family owners. We expect the presence of a family as the second large shareholder to adversely impact the cost of equity, because theoretical and empirical studies suggest that family owners are often associated with corporate wrongdoings. For instance, Almeida and Wolfenzon's (2006) model suggests that 
diverting corporate resources is more likely to take place in family business groups. Villalonga and Amit (2006) show that excess control is associated with a value discount, in founder-led firms, when families use control-enhancing mechanisms to increase their vote ownership over and above their share ownership. Similarly, Claessens et al. (2002) show that excess control is associated with value discounts in family-controlled firms. Attig et al. (2006) report evidence that liquidity costs and asymmetric information are more prominent in family firms. ${ }^{11}$ Additionally, one may expect a weaker governance role by the state, and therefore a positive relation between the cost of equity capital and the presence of the state as a second shareholder. Nevertheless, the desire of the state to maximize proceeds from future privatizations (see, for example, Megginson and Netter (2001)) can plausibly advocate its efficient monitoring role. Finally, the sharing of private benefits between a controlling family and a financial institution seems unlikely because the latter's interest is more vested in protecting its reputation.

\subsection{Cost of Equity Estimates}

A more direct measure of the expected return concept in asset pricing theory is an asset's ex-ante expected return rather than the commonly used mean of realized returns. ${ }^{12}$ Not surprisingly, in recent years ex-ante cost of equity capital based on discounted cash flow valuation methods has gained popularity in accounting and finance research (e.g., Francis et al. (2004), Botosan and Plumlee (2005), Hail and Leuz (2006), Dhaliwal et al. (2005, 2006), among others). We follow these studies by using the discount rate implicit in the current stock price, book value per share, dividend payout, and analyst earnings forecasts. The basic idea is simple: as the share price is the present value of expected future cash flows per share, the rate that

11 Existing studies, however, do not provide unequivocal evidence on the valuation effect of family control. Anderson et al. (2003) show that, in large U.S. firms, minority shareholders benefit from the presence of family control. Nevertheless, Anderson et al.'s (2003) evidence is likely to be most tenable in the U.S. Barontini and Caprio (2005) and Maury (2006) find that family control is better than other types of control for firm value and operating performance in European firms. However, Wang (2006) outlines that the entrenchment effect may induce family firms to opportunistically manage their earnings to deflect attention from their potential expropriation of corporate resources.

12 Elton (1999) emphasizes the need to find an alternative proxy for expected returns, citing realized return as a poor and potentially biased proxy for expected return. In the same line, Fama and French $(1997,2004)$ conclude that the single factor CAPM (Sharpe (1964) and Lintner (1965)) and the FamaFrench three-factor model both offer a very poor proxy of a firm's cost of equity capital. Detailed discussion on this topic is beyond the scope of this paper. 
makes the present value of expected future cash flows per share equal to the share price must be the true discount rate of the firm. In particular, we estimate the cost of equity capital based on four commonly used models; namely, Ohlson and Juettner-Nauroth (2005 OJ), Easton (2004 ES), Gebhardt, Lee, and Swaminathan (2001 GLS) and Claus and Thomas (2001 CT), which we denote $\mathrm{K}_{\mathrm{OJ}}, \mathrm{K}_{\mathrm{ES}}, \mathrm{K}_{\mathrm{GLS}}$ and $\mathrm{K}_{\mathrm{CT}}$, respectively. All these models allow estimation of the cost of equity capital for a firm-year without relying on historical data for several years. In addition, in empirical tests, cost of equity estimates of these models exhibit loadings with a majority of risk factors, as predicted by theory and shown in Gode and Mohanram (2003), Gebhardt, Lee and Swaminathan (2001), Dhaliwal et al. (2005, 2006), and Daske (2006). However, given little guidance from the literature about the validity and empirical superiority of a particular model, we use the average of the cost of equity estimates derived from the above four models to measure firms' cost of equity capital $\left(\mathrm{K}_{A V E R A G E}\right)$. For example, while evidence in Botosan and Plumlee (2005) suggests that $\mathrm{K}_{\mathrm{GLS}}$ is an inferior proxy for the cost of equity compared to estimates based on other discounted valuation models, Guay et al. (2005) find that $\mathrm{K}_{\mathrm{GLS}}$ is the best predictor of expected returns. As such, using the average of cost of equity estimates derived from various models reduces the possibility of spurious results arising from the use of a single model (Dhaliwal et al. (2006)). Appendix A.1 provides details on the implementation of these four models in estimating firms' cost of equity capital.

Table 1 provides descriptive statistics for the implied cost of equity estimates. Panel A reports the average implied cost of equity across the sample countries. The correlation coefficient (unreported) between Hail and Leuz's estimates and our estimates of the countryaverage implied cost of equity is about 70\% (rank correlation $75 \%$ ). ${ }^{13}$ The pairwise correlation

\footnotetext{
${ }^{13}$ While we report a high correlation of our country average cost of equity estimates with those of Hail and Leuz (2006), the average cost of capital estimates we report by country are not necessarily representative of the country's overall cost of capital due to limited observations represented in the sample by country. For example, our sample has 45 observations for Finland and 201 for Malaysia. Therefore, it is not surprising to observe a lower average cost of capital for Malaysia (an emerging market) compared to that of Finland (a developed market). Yet, our country averages are comparable to Hail and Leuz (2006); e.g. in ranking by country average cost of capital, three out of four lowest ranked and three out of four highest ranked countries are the same in Hail and Leuz and this study. Hail and Leuz also report a higher cost of capital for Finland (13.40\%) compared to that of Malaysia (10.65\%). Further, a simple comparison of country averages may be misleading (Hail and Leuz, 2006). For this reason we, in line with the literature, control for several firm-specific risk factors before introducing MLS variables in our tests. Finally, in this study we do not make direct inferences about country differences in cost of equity capital.
} 
coefficients between cost of equity estimates based on the various models are reported in Panel B of Table 1. The correlations of model cost of equity estimates with the firm's ultimate cost of equity range from $75 \%$ ( $\mathrm{K}_{\mathrm{GLS}}$ vs. $\left.\mathrm{K}_{\text {AVERAGE }}\right)$ to $92 \%$ ( $\mathrm{K}_{E S}$ vs. $\left.\mathrm{K}_{A V E R A G E}\right)$.

Panel C presents descriptive statistics of the cost of equity estimates of the four different models and $\mathrm{K}_{A V E R A G E}$. The cost of equity estimates of abnormal growth models $\left(\mathrm{K}_{O J}\right.$ and $\left.\mathrm{K}_{E S}\right)$ are on the higher side compared to the residual income valuation models ( $\mathrm{K}_{C T}$ and $\mathrm{K}_{\mathrm{GLS}}$ ). The average $\mathrm{K}_{O J}$ is the highest and the average $\mathrm{K}_{\mathrm{GLS}}$ is the lowest, consistent with Gode and Mohanram (2003), Dhaliwal et al. $(2005,2006)$, and Hail and Leuz (2006). In other words, the $\mathrm{K}_{O J}$ is the upper bound and $\mathrm{K}_{\mathrm{GLS}}$ is the lower bound of our cost of equity estimates. $\mathrm{K}_{A V E R A G E}$ is the ultimate cost of equity estimate. The mean $\mathrm{K}_{A V E R A G E}$ is $12.3 \%$ with a standard deviation of $5 \%$.

Overall, we assert that our estimates are fairly representative of firms' true cost of equity capital. Indeed, the statistical properties of our cost of equity capital estimates described above do not substantially differ from those reported in recent studies. ${ }^{14}$ However, we echo their acknowledgement that these estimates suffer from limitations of earnings forecasts and growth rate assumptions.

\section{Empirical Evidence}

\subsection{Regression Specifications}

Our analysis of the relation between MLS and cost of equity capital lies at the intersection of the literatures on corporate ownership structure and cost of capital, which suggest that excess control engenders agency problems and information asymmetry between the controlling owner and other shareholders and, in turn, influences the cost of capital. While

\footnotetext{
14 The mean of the cost of equity estimates for 40 countries in Hail and Leuz (2006) for the models $\mathrm{K}_{O J}$, $\mathrm{K}_{E S}, \mathrm{~K}_{C T}$, and $\mathrm{K}_{G L S}$ are $14.59 \%, 13.96 \%, 12.17 \%$, and $9.25 \%$, respectively. Our estimates of the overall average cost of equity not only have the same ordering across models, but also are very close in magnitude. Similarly, the correlations of the individual cost of equity estimates and $\mathrm{K}_{\text {AVERAGE }}$ resemble those reported in Hail and Leuz (range from 74.7\% to 95.9\%). There are, however, two differences: first, our estimates of correlations are based on firm-year observations, while the latter are based on countryyear averages; second, Hail and Leuz's estimates are in the local currency of each country, while our estimates are in a common currency (U.S. dollars) in line with several other cross-country studies (e.g., Harvey (1995), Erb et al. (1996), Bekaert and Harvey (1995), Mishra and O'Brien (2005)). We use the exchange rate for the forecast record date and convert earnings forecasts, book value, and stock prices into U.S. dollars.
} 
theoretical studies analyzing the governance role of MLS are elusive, empirical research is also scarce. Our analysis helps rectify this oversight by investigating the role of MLS in limiting the potential expropriation of minority interests by the ultimate owner. We regress firms' cost of equity capital on MLS-related variables capturing presence, size and identity, while we control for excess control of the largest shareholder and other firm- and country-level determinants of the cost of capital. More specifically, we estimate several specifications of the following crosssectional, time-series model (subscripts suppressed for notational convenience):

$$
K_{A V E R A G E}=\alpha_{0}+\alpha_{1} \text { MLS }+\alpha_{2} \text { Controls }+ \text { Fixed Effects }+\varepsilon
$$

We specify the regression variables as follows:

$K_{A V E R A G E}=$ the average implied cost of equity capital based on four different models discussed in Section 2.2 and described in Appendix A.1;

$M L S=$ variables related to the presence and size of multiple large shareholders discussed in Section 2.1;

Controls $=$ a set of firm- and country-level control variables outlined below;

Fixed Effects = dummy variables controlling for fixed effects of countries, years, and industry groups based on the one-digit SIC codes; and

$\varepsilon=$ an error term.

To isolate the effects of MLS-related variables - our key test variables - we control for the potential impact of other factors shown in previous studies to influence the cost of equity capital. ${ }^{15}$ Specifically, we control for: (i) the controlling owner's incentives to expropriate minority shareholders, measured by the difference between control rights and ownership rights (Excess1); (ii) the number of analysts providing earnings forecasts (Analyst Coverage), which is expected to be negatively related to the cost of equity capital (Gebhardt et al. (2001)); (iii) the accuracy of analysts' forecasts measured with the standard deviation of the first year analyst forecasts divided by mean earnings forecasts (Variance of Analyst Forecasts), which is expected to be positively related to the cost of equity capital (Gode and Mohanram (2003), Botosan and Plumlee (2005), Dhaliwal et al. (2006)); (iv) growth rate proxied by the average of I/B/E/S fiveyear earnings growth rate for each available month in a year (Growth), which is expected to positively influence the cost of equity capital (Gode and Mohanram (2003), Lee et al. (2004)); (v) the ratio of market value to book value of equity (Market to Book), which is expected to be

15 Our choice and specification of these controls closely follows Gebhardt et al. (2001), Gode and Mohanram (2003), Botosan and Plumlee (2005), Dhaliwal et al. (2005), Hail and Leuz (2006), and Guedhami and Mishra (2008). 
negatively associated with the cost of equity capital, given evidence in Botosan and Plumlee (2005) and Hail and Leuz (2006), consistent with the finding that higher book to market (lower Market to Book) firms earn higher ex-post returns (Fama and French (1992)); (vi) firm's leverage, which we proxy with the ratio of total debt to total capital (Leverage), and which is expected to be positively correlated with the cost of equity capital, as predicted by theory (Modigliani and Miller (1958), Hamada (1969)) and confirmed by empirical evidence (Fama and French (1992), Gode and Mohanram, (2003), Botosan and Plumlee (2005), Dhaliwal et al. (2006)); (vii) firm risk captured with the standard deviation of annual prices over four years divided by the average annual price (Volatility), which is expected to be positively related to the cost of equity (Hail and Leuz (2006)); ${ }^{16}$ and (viii) the industry cost of capital measured as the average of $\mathrm{K}_{A V E R A G E}$ at twodigit industry codes (Industry Cost of Capital), which is expected to positively influence the firm's cost of equity capital (Gebhardt et al. (2001)).

Table 2 provides descriptive statistics of all explanatory variables. Motivating our investigation of their governance role, we find that control by multiple large shareholders exists in $44 \%$ of the sample firms. For the subsample of firms with multiple large shareholders the second largest shareholders hold, on average, $13.81 \%$ of voting rights, while the total voting rights held by the four largest shareholders, beyond the controlling owner, is $19.64 \%$. For the total sample of firms, the relative power of the second largest shareholder (all multiple large shareholders) relative to the controlling owner is $0.27(0.39)$, on average.

To more fully explore the interaction between the different coalitions of large shareholders we present, in Table 3, a descriptive summary of the distribution of the shareholder type. We note that family shareholders dominate the position of the largest shareholder in $43.5 \%$ of the closely-held firms in our sample (Panel A). This proportion decreases sharply for bank (12.3\%) and state (9.4\%). Equally important, Panels B, C, and D of Table 3 uncover several interesting empirical findings about the distribution of blockholders. First, Panel B suggests that the presence of family as a blockholder, beyond the family-family coalition of the two largest shareholders, is more pronounced than the presence of the other

\footnotetext{
${ }^{16}$ We use price volatility as the proxy for a firm's market risk given that recent empirical studies (e.g., Gebhardt et al. (2001) and Lee et al. (2004)) show that beta exhibits little or no association with the implied cost of capital. The return volatility is shown to be a better proxy for firm's market risk (e.g., Lee et al. (2004), Mishra and O’Brien (2005), Hail and Leuz (2006)).
} 
types of shareholders. Second, Panels C and D suggest that for the family-state and family-bank coalitions the presence a financial institution as a major shareholder, beyond the largest two shareholders, is more pronounced than the other types. These results, together with the fact that $54.7 \%$ of the family-family coalitions have no direct control contestability from other shareholders (i.e., absence of other blockholders), allow us to posit that, all else equal, the family-family coalition may plausibly be associated with an alignment of interests of the two largest shareholders (i.e., families), who might find it mutually valuable to collude to extract divisible private benefits of control.

Table 4 presents Pearson's correlation coefficients between these variables. We generally report low pairwise correlation coefficients among the control variables and especially between our test variables (as defined in section 2.1) and the determinants of the cost of capital, mitigating the concern that multicolineraity could be affecting our multivariate regression results. As expected, there is substantial correlation between the key test variables; however, two highly correlated test variables do not enter the same regression.

3.2 Evidence of the Impact of MLS and Large Shareholder Identity on the Cost of Equity Capital: Full Sample

In Table 5 we report the multivariate regression results from estimating Equation (1) for the full sample. All models control for the determinants of the cost of capital reported in the previous studies and discussed above. In interpreting the results, we primarily focus on the effects of MLS-related variables. In Model 1, our basic regression indicates a positive and statistically significant coefficient for Excess1 (at the 5\% level), suggesting that the separation between ownership and control rights of the ultimate owner increases the cost of equity capital. This result lends support to recent evidence that firms with excess control incur higher financing costs to compensate for severe information problems (e.g., Guedhami and Mishra (2008)). In Models 2 through 9, we separately include our key test variables. In Model 2, we start by examining whether the mere presence of MLS beyond the ultimate owner influences the firm's cost of equity. We find that the coefficient for Presence 2 is negative and statistically significant at the $1 \%$ level. In other words, this relation implies lower financing costs for firms with multiple large shareholders compared to firms with a single controlling shareholder, consistent with the efficient-monitoring hypothesis. Additionally, we estimate in Model 3 a 
negative and statistically significant (at the 1\% level) coefficient for Nowners2345, suggesting that the presence of a large number of controlling shareholders is economically material to reducing firm's cost of equity. This evidence, in line with the theoretical models of Bennedsen and Wolfenzon (2000), Gomes and Novaes (2005) and Pagano and Roell (1998), suggests that shared control (i.e., the presence of MLS), as an internal governance mechanism, is likely to mitigate firm's agency costs, and therefore benefit minority interests.

In the rest of Table 5, we report the results for more stringent MLS variables measuring the contestability of the controlling shareholder's power. Model 4 reports a negative and significant (at the 5\% level) coefficient for Cont2, suggesting that firms' cost of equity capital decreases with the size of the second largest shareholder. This finding is further confirmed in Model 5, which includes the total voting rights of the four controlling shareholders beyond the largest one. Indeed, the coefficient for Cont2345 is negative and statistically significant at the 1\% level. These findings indicate that not only the presence of MLS, but also the size of the voting rights of the blockholders, is economically significant in reducing firm's agency costs.

We further probe the influence of MLS on firms' cost of equity by first examining the effects of the relative voting power of the second shareholder (Voting2\%1), and then of the four controlling shareholders (Voting2345\%1) relative to the largest controlling shareholders. Results are reported in Models 6 and 7 of Table 5, respectively. Interestingly, the negative and statistically significant estimates for Voting $2 \% 1$ and Voting $2345 \% 1$ imply that minority interests will benefit from the presence of large controlling shareholders with votes of comparable sizes. Indeed, the reduced cost of equity associated with the presence of such blockholders lends support to the efficient-monitoring hypothesis of the MLS. This evidence corroborates the argument that more equality in the voting rights among the blockholders improves corporate governance (e.g., Bloch and Hege (2001), Maury and Pajuste (2005)). This evidence is further supported by the estimated positive and significant coefficient (at the 5\% level) for Hi_Differences reported in Model 8. This relation suggests that uneven distribution of control rights among large shareholders reduces the effectiveness of MLS monitoring. Stated differently, the results so far indicate that a high risk of control contestability (of the largest controlling shareholder) is associated with firm's enhanced information quality and thus lower cost of equity capital. Finally, we do not find a statistically significant effect of the power of the 
ocean on the firm's cost of equity, suggesting that minority interests do not seem to have a relevant role in mitigating agency costs in our sample firms. Overall, the results in this section suggest that MLS play a valuable information role by lowering the cost of equity capital for firms with severe information problems embedded in their ownership structures.

Turning to the control variables, we observe several significant relations consistent with extant cost of capital studies. First, we report a negative and highly significant coefficient for Analyst Coverage-our proxy for firm size and information availability-across all models, which is consistent with Fama and French (1992) and Gebhardt et al. (2001). Second, we find that analyst forecast accuracy (Variance of Analyst Forecasts) is consistently positive and statistically significant at the 1\% level, in line with Gode and Mohanram (2003) and Dhaliwal et al. (2006). Third, we find positive and significant (at the $1 \%$ level) relations across all models between the cost of equity capital and firm's risk, growth, leverage and industry cost of equity, in line with prior empirical research on the cost of capital. Finally, we find that the coefficient for Market to Book is negative and significant at the $1 \%$ level across all models, consistent with Gode and Mohanram (2003), Botosan and Plumlee (2005), and Hail and Leuz (2006).

In Table 6, we examine whether the interactions between large shareholders of different types contribute to explaining firms' cost of equity. We specifically focus on whether the type of the second large shareholder improves monitoring of a particular class of controlling owner, namely family firms (around 44\% of the sample firms). Model 1 of Table 6 presents a positive and significant (at the 5\% level) coefficient for the variable Cont2*Family-Family. This implies that when the two largest shareholders are families, the market perceives greater risk of expropriation of minority shareholders and requires higher rates of return. Two arguments can be advanced to explain this result. The market's anticipation of increased levels of corporate expropriation can be driven from the monitoring passivity of the second shareholders, who might remain neutral rather than engage in monitoring activities, thereby participating in potential extraction of private benefits. Alternatively, the second largest shareholder may collude with the largest shareholder and actively engage in diverting corporate resources to extract divisible private benefits.

Model 2 presents a negative and highly significant coefficient for Cont $2 *$ Family-State, suggesting that when the largest shareholder is a family and the second largest shareholder is a 
state, the cost of equity is negatively associated with the voting rights of the second largest shareholder. We interpret this result as conveying two complementary messages. First, it implies that the presence of the state as a second large shareholder is not associated with corporate expropriation, even in family firms. Second, and more importantly, it indicates that the larger voting right of the state is substantially instrumental in controlling diversion of firm's resources by the largest shareholder (controlling family). Although this result may seem surprising, as one may expect a weaker governance role by the state, the desire of the state to maximize proceeds from future privatizations (see, for example, Megginson and Netter (2001)) can plausibly advocate its efficient monitoring role. In Model 3 the estimated coefficient of the variable Cont ${ }^{*}$ Family-Bank indicates that the association between a family, as the largest shareholder, and a widely-held bank, as the second shareholder, does not impact the cost of equity capital. ${ }^{17}$

In summary, this section reinforces evidence that the corporate governance role of MLS is substantial and significantly affects the firm's equity financing costs. In particular, the size of the second largest shareholder's voting rights-both absolute and in relation to that of the largest shareholder-is not neutral in reducing the risk of expropriation of minority shareholders. The second largest shareholder in aggregate plays an important corporate governance role as a safeguard of her/his own and other minority shareholders' collective interests. Also, the lower wedge among the voting rights of the large shareholders effectively reduces such risk. Notwithstanding this evidence, the monitoring role of the second largest shareholder appears to depend on its identity. Indeed, the presence and the voting rights of the state as a second largest shareholder seem to have an economically significant impact in mitigating firm's agency costs, and ultimately reducing firms' cost of equity capital. However, if the second largest shareholder in a family-controlled firm is also a family, the market perceives a greater likelihood of expropriation through coalition, and thus requires a greater rate of return in the equity investment. By showing a strong negative effect of the presence, the number, and

\footnotetext{
17 We urge caution when interpreting this evidence as it suggests that either financial institutions might be less independent as monitors, probably because of their potential commercial relationship with the firm (e.g., Pound (1988)), or they defuse the potential diversion by the largest controlling shareholder. Put together, these results on the interactions of various types of large shareholders are in line with the descriptive statistics in Table 3. Indeed, we document that family-bank, as well as the family-state coalition, is usually associated with a more pronounced presence of controlling shareholders which are other than the family type, whereas the inverse is true for the family-family coalition.
} 
the relative voting size of the multiple shareholders on the cost of equity capital, and by emphasizing the importance of second shareholder identity in alleviating firm's agency costs, the evidence in this paper helps explain the channel through which multiple shareholders enhance firm value. ${ }^{18}$ The evidence in this section is based on the pooled sample of Asian and Western European firms. Below we investigate the differences in the results between the two regions.

3.3 Evidence of the Impact of MLS and Large Shareholder Identity on the Cost of Equity Capital: Regional Analysis

Our multinational sample covers countries from institutionally different regions: East Asia and Western Europe. In this section we examine whether the previous evidence on the governance role of MLS, manifest in firm's cost of equity, persists in both regions or is driven by a particular region. Relevant to our regional analysis is the fact that ultimate ownership structures differ substantially between the two regions. For instance, Faccio and Lang (2002, p. 367), by contrasting their findings on ultimate ownership structures of firms from Western Europe to those of Claessens et al. (2000) for East Asia, document that "...the largest shareholder is less often alone, but averages much higher cash-flow rights, control rights, and ratio of cash-flow to voting rights. These differences may be due to weaker law enforcement in Asia that allows controlling owners to achieve effective control of a large number of firms by controlling and owning a smaller part of each firm." Arguably, the results of Faccio and Lang's (2002) insightful comparison suggest that the risk of corporate diversion is higher in East Asia than in Europe. ${ }^{19}$ Accordingly, one would expect differences in the governance role of MLS across the two regions. It is plausible to expect a more valuable role of MLS in East Asia, probably to sidestep a deficient external institutional environment (e.g., weak protection, fragile law enforcement, etc.).

\footnotetext{
18 Prior related research suggests that the presence and relative size of voting rights of the second largest shareholder, and lesser wedge in the control size of large shareholders, positively affect firm value (e.g., Pagano and Roell (1998), Maury and Pajuste (2005), Laeven and Levine (2007)).

19 Consistent with this explanation, empirical evidence in Faccio et al. (2001), Fan and Wong (2005), El Ghoul et al. (2007) imply that the potential for expropriation is more serious in East Asian firms.
} 
Table 7 replicates the results of Tables 5 and 6 separately for East Asia and Western Europe. The results suggest significant differences in the role of MLS between the two regions. Notably, we find that almost all MLS proxies are statistically significant at the $1 \%$ level in East Asia. In contrast, with the exception of Hi_Differences (proxy for the contestability of the power of the controlling owner) and Shapley5 (proxy for the power of the small shareholders), none of the MLS variables is statistically significant in Western Europe. The economically significant coefficient of the Shapley value for European firms is appealing. Knowing that Shapley value reflects the power of the ocean (i.e. minority interests), the negative and significant coefficient for Shapley5 suggests that the cost of equity capital is decreasing in the power of the ocean, providing supportive evidence to the better protective environment of minority shareholders in Western Europe. Collectively, these contrasting results on the impact of MLS on the cost of equity capital suggest that the monitoring role of MLS is more valuable in East Asian corporations where the potential for expropriation is more pronounced. To some extent, this conclusion is consistent with the differences in the scope and significance of agency problems in firms from East Asia and Western Europe (e.g., La Porta et al. (1999), Faccio and Lang (2002)).

Second, the results on the impact of the identity of the second largest shareholder reveal divergent effects across the two regions. While the coefficient for Cont $2 *$ Family-Family is positive and statistically significant at the $10 \%$ level for the Asian subsample, it is insignificant for the European subsample, suggesting that our earlier finding of higher potential for expropriation when the two largest shareholders are families tends to hold in Asia. An important difference between the two regions relates to the role of the state and banks as second shareholders. The coefficient for Cont ${ }^{*}$ Family-State is negative and highly significant in Asia, but positive and highly significant in Europe, suggesting that the cost of equity capital of family firms in Asia (Europe) is decreasing (increasing) in the voting rights of the state. A similar result is obtained for the coalition family-bank, suggesting that investors (do not) perceive a significant governance role by a widely-held financial institution as a (second) major shareholder in East Asia (Europe). Perceptibly, the magnitude of the estimated coefficients of the family-bank coalition, across the two regions, is comparable but of opposite sign. To some extent, this might explain the non-significance of the estimated coefficient of the family-bank in our pooled sample. 


\section{Sensitivity Tests}

In order to more fully explore the reliability of our results, we subject our estimates to a large battery of robustness checks. We start by examining the stability of our results to alternative estimates of the dependent variable: cost of equity capital. As motivated above, we follow recent research and use four variations of accounting-based residual income valuation models to derive our measure of the cost of equity. Alternatively, we re-run our main regressions in Table 5 and 6 using the expected return estimates based on the traditional singlefactor capital asset pricing model (CAPM) and Fama-French three-factor model (FF-TFCAPM) (Fama and French (1993)). In the traditional CAPM, the market factor is the total monthly return on the value weighted portfolio less the risk-free proxy (three-month US Treasury Bill). Likewise, FF-TFCAPM includes three Fama-French benchmark factors: market factor (the same as in CAPM), size factor SMB (Small-minus-Big), and value factor HML (High-minus-Low). ${ }^{20}$ The results of these tests that replicate Tables 5 and 6 are reported in Table 8. Using the same set of controls as in the previous tests, we find that all MLS proxies load with negative and significant coefficients, suggesting that MLS reduce the cost of equity capital, consistent with our earlier

20 To generate the cost of equity estimates using the FF-TFCAPM, we employed the following methodology. For each country in our sample, we construct six portfolios (Small/Low, Small/Medium, Small/High, Big/Low, Big/Medium, Big/High) from the combination of the two sizes (small vs. big, as measured by the firm market capitalization) and three book-to-market groups (low, medium, and high). Monthly value weighted returns on the six portfolios are calculated from July of year $t$ to June of $t+1$, and the portfolios are reformed in June of $t+1$. Our first factor is the total monthly return on the value weighted portfolio less the risk-free proxy (three-month US Treasury Bill). Our second factor, small minus big (SMB) portfolio, is the difference between the returns on small and big stock portfolios for the same weighted average book-to-market equity. In other words, the size factor, in each month, is the difference between the average of the returns on the three small stock portfolios (Small/Low, Small/Medium, Small/High) and the average of the returns on the three big-stock portfolios (Big/Low, Big/Medium, Big/High). We use this approach to free our size factor from any influence of book-tomarket. Our third factor, high minus low (HML), is the monthly difference between the average of the returns on the two high book-to-market portfolios (Small/High and Big/High) and the average of the returns on the two low book-to-market portfolios (Small/Low and Big/Low). We derive our data from Compustat Global Vantage database. We impose a filter of a minimum 24 monthly returns. In matching with our original sample, we obtained 2,079 $(2,060)$ firm-years with valid cost of equity estimates using the CAPM (FF-TFCAPM). 
evidence for the full sample. We also continue to find that the voting rights of the state as a second largest shareholder lower the cost of equity in family firms. ${ }^{21}$

Our main proxy of the firm's cost of equity is derived from averaging four different cost of equity estimates. The motivation for using this proxy is to mitigate the possibility that our findings are attributable to a single model. The main points of our analysis do not change materially when we use the average cost of equity over our sample period as reported in Model 3 of Table 8.22 In Model 4 of Table 8, we replicate the tests reported in Tables 5 and 6 using the cost of equity derived from Claus and Thomas's (2001 CT) model. In unreported tests that use other individual cost of equity estimates, we also find practically similar evidence, although it tends to be stronger and highly statistically significant for the residual income valuation models (e.g., GLS and CT) and weaker for the abnormal growth model (e.g., OJ and ES model). ${ }^{23}$ Overall, the results remain qualitatively similar to our earlier findings, even when we use the average of each model's specific cost of equity estimates (e.g., $\mathrm{K}_{C T}$ ) over the three-year sample period.

The results of our second set of robustness checks are reported in Table 9. We test whether country-specific risk has a substantial effect on firms' cost of equity capital, as indicated in prior literature. For example, Bansal and Dahlquist (2002) report a strong empirical relationship between mean realized returns on emerging market indexes and various measures

${ }^{21}$ The evidence in subsection 3.3 suggests a more valuable monitoring role of large shareholders in Asia compared to Western Europe. In unreported results, this evidence is also supported when we test the effect of MLS proxies across the two regions using alternative cost of equity estimates derived from the CAPM and FF-TFCAPM.

22 To ensure ample variation in MLS variables, we use all firm-year observations over our sample period for which the cost of equity estimates are available. Indeed, given the data collection requirements outlined in Section 2.1, a valid observation for the cost of equity is not available in each year. However, our core findings, including the effects of controlling shareholders identity and those suggesting differences in the role of MLS between Asia and Europe, remain qualitatively similar when we estimate the models for 1996, although the number of observations declines substantially.

${ }^{23}$ In this line of research, motivation behind using the average of the cost of equity estimates of several models is to mitigate potential likelihood of spurious results due to the particular assumptions of a single model. Therefore, any difference in significance of coefficients and power of tests across model estimates is not surprising. For example, Dhaliwal et al. (2006, p. 699) argue that "Limiting empirical analysis to just one measure may produce spurious results if particular attributes of the model are correlated with the variable of interest. To mitigate the effect that particular assumptions of each model might have on our results, we use the average of the four implied cost of equity estimates in our empirical tests." 
of country political risk ratings. Similarly, Erb et al. (1996) and Harvey (2000) find a significant association between country credit ratings and the cost of capital in a cross-country analysis. In order to determine if our results are driven by country-specific risk, we control for country credit ratings measured by the natural logarithm of 100 minus Institutional Investor country ratings in all models reported in Table 6.24 The results, reported in Models 1 and 2 of Table 9, indicate that the coefficient for this control is positive and statistically significant (at the $1 \%$ level) while the magnitude and significance of the key test variables (Presence2 and Voting2\%1) are not affected by including this control. This suggests that our prior findings are not driven by firms' country-specific risk exposure.

We also control for forecast bias which captures earnings variability (Gebhardt et al. (2001)) and firm's tendency to provide forecasts that surprise the market. Firms reporting substantial and frequent earnings surprises are expected to exhibit higher cost of capital (Mikhail et al. (2004)). In particular, our sample covers firms from several countries, and the tendency of forecasters to provide less or more optimistic forecasts is likely to vary across countries due to accounting practices. For example, Capstaff et al. (2001) report substantial differences in forecast bias across nine European countries. To address the concern that the forecast bias may be driving our cost of equity estimates and results, we consider it important to control for forecast bias. Following Hail and Leuz (2006) and Guedhami and Mishra (2008), we use as a proxy the difference between one-year-ahead mean analyst earnings per share forecasts and the corresponding actual (realized) earnings per share reported in I/B/E/S, which we denote Forecast Bias. The results reported in Models 3 and 4 of Table 9 show that the coefficient for Forecast bias is positive and statistically significant at the $1 \%$ level, consistent with Hail and Leuz (2006). Importantly, the MLS variables Presence2 and Voting2\% 1 continue to load negative and statistically significant at the $1 \%$ and $5 \%$ levels, respectively, providing further support to the results reported in Tables 5 and 6 .

Third, if the coalitions between large shareholders form to expropriate minority shareholders, then the largest shareholder with substantial excess control will have an incentive to actively pursue such coalitions. Accordingly, if the identity of large shareholders is important for forming such coalitions, the largest shareholder holding excess control will actively motivate

\footnotetext{
${ }^{24}$ We extract country credit ratings from Institutional Investor for the month of September of each year.
} 
the second largest shareholder of similar identity and substantial control to join the coalition. This brings up another possibility that, if tested in the subsample of firms that exhibit excess control of the largest shareholder, the results presented in section 3.2 should be stronger. We test Models 2 and 3 of Table 6 using the subsample of firms with a strictly positive value for Excess1. Supporting this prediction, we find that the coefficient for Cont2*Family-State is negative and statistically significant at the $1 \%$ level, while the coefficient for Cont ${ }^{*}$ FamilyFamily is positive and statistically significant at the 1\% level (Models 5 and 6 , respectively, of Table 9). We further partition this subsample of firms into groups - one with a higher level of wedge $($ Excess $1>10 \%)$ and another with a lower level of wedge $(0<$ Excess $1<=10 \%)$. As reported in Table 9, we find that the coefficient for Cont ${ }^{*}$ Family-State is negative and statistically significant at the $1 \%$ level in both subsamples of firms with higher wedge (Model 7) and lower wedge (Model 9). Further, we find that the coefficient for Cont2*Family-Family is positive and significant in the subsample of firms with higher wedge (Model 8) and, not surprisingly, it is not significant for the subsample of firms with a lower level of wedge between voting and cash flow rights (Model 10). This evidence lends further support to the conclusion that the identity of large shareholders is important in shaping the effect of MLS on firms' cost of equity. Our predictions also hold when we run these regressions for the subsamples of firms in which the two largest shareholders have wedge between voting and cash flow rights greater than zero (Excess1>0 \& Excess2>0) (Models 11 and 12); only the firms from Western Europe remain in this subsample.

Fourth, most other studies (e.g., Claus and Thomas (2001), Gebhardt et al. (2001), Gode and Mohanram (2003)) use the excess of the cost of equity over the risk-free rate (defined here as Risk Premium) as the dependent variable, unlike our study and that by Hail and Leuz (2006). The primary reason for using Risk Premium is to isolate the time series variation in the risk free rates (thus the cost of equity). ${ }^{25}$ Although our main regressions reported in Tables 5 and 6 control for year fixed effects to account for the time series variation in the cost of equity, we also examine the sensitivity of our results to using Risk Premium as the proxy for the cost of equity

${ }^{25}$ In cross-country studies, the use of Risk Premium also serves as a control for the effect of inflation differences across countries (e.g., Hail and Leuz (2006)). However, inflation differences are not a concern in our analysis as we estimate the cost of equity in a common currency (U.S. dollars). In using this approach, for simplicity, we assume that exchange rates reflect cross-country differences in inflation premium. 
capital. Following most cross-country studies, which estimate cost of equity in U.S. dollars (e.g., Bekaert and Harvey (1995), Harvey (1995), Lee et al. (2004)), we subtract U.S. Treasury bill yield from the cost of equity to estimate Risk Premium. In unreported results, our core findings in the previous section remain qualitatively unaffected by using Risk Premium as the dependent variable.

Fifth, Laeven and Levine (2007) report that the wedge between the relative cash flow rights of the two largest shareholders (Cash1 and Cash2) negatively affects firm value. We are not able to verify this in our full sample as Asian firms do not have cash flow rights for the second largest shareholder. However, using the Western European subsample of firms we test whether the wedge between cash flow rights is positively associated with firms' cost of equity. In unreported results, the coefficient of (Cash1-Cash2) is positive, but statistically insignificant at the $10 \%$ level.

Sixth, in reported regressions Analyst Coverage is an information variable serving the same purpose as firm size. Indeed, more analysts are expected to follow larger firms, causing them to face lower information asymmetry. In order to test whether our results are sensitive to using an alternative proxy for firm size, we control for firm size using the average of the natural logarithm of total sales and the natural logarithm of total assets. The unreported results indicate that the coefficient for firm size is negative and statistically significant (at the $1 \%$ level) in all models of Tables 5 and 6. However, none of our previous findings are affected when using this alternative proxy for firm size as the information variable, although the explanatory power of models that include Analyst Coverage is greater.

Seventh, a country's legal and institutional environment is expected to affect the largest shareholder's ability to expropriate minority shareholders, and the multiple large shareholders' ability to collude to expropriate other shareholders. Therefore, we also control for countryspecific legal institutional variables. Our results (unreported) remain practically unchanged after using several legal institutional control variables collected from La Porta et al. $(1998,2006)$; namely, the level of minority shareholders' protection against managers or controlling shareholders (antidirectors rights index), the efficiency of the judiciary system, an assessment of the strength of law and order, and an assessment of the quality of disclosure requirements (Disclosure). For example, when controlling for disclosure requirements and antidirector rights 
in separate regressions, all MLS test variables maintain their sign and significance, except for Hi_Differences, which is positive but statistically insignificant.

\section{Conclusion}

The ultimate purpose of this research is to investigate whether the presence, the voting rights, and the relative control of multiple large shareholders play an effective corporate governance role in mitigating information asymmetry between the controlling owner and minority investors, thereby rendering them instrumental in reducing firm's equity financing costs. Further, we explore the effect of second shareholder identity in family-controlled firms. We find robust evidence that the implied cost of equity decreases in the presence of large shareholders beyond the controlling owner. In additional tests, we find that the voting rights, the relative voting size (vis-à-vis the first largest shareholder) and the number of blockholders lowers firm's cost of equity capital. We also find that uneven distribution of control rights among large shareholders reduces the effectiveness of MLS monitoring. Stated differently, the presence of multiple controlling shareholders with comparable voting power mitigates firm's agency costs and lowers firm's cost of equity capital, plausibly because a high control contestability (of the largest controlling shareholder) is likely to enhance firm's information quality and thus lower cost of equity capital. We also find that the identity of the second largest shareholder is important in shaping the risk of corporate expropriation in family-controlled firms. In particular, we find that when the two largest shareholders are families, the information risk is high and, therefore, so too is the implied cost of equity. We conclude that the discount rate is a significant channel through which the market prices the monitoring role of multiple large shareholders in limiting the diversion of firm's resources for private benefits. The market seems to take into account both the identity and voting size of the second largest shareholder in pricing this role in family-controlled firms. It assigns a positive risk premium when the second largest shareholder is a family and a negative risk premium when it is the state. However, regional analysis reveals that our conclusions from the pooled sample (of European and East Asian firms) are mainly defensible in East Asia, reflecting the severe agency problems and weak institutional protection in this region.

As in all empirical work, a number of caveats should be noted. Perhaps the most important, and similar to most extant corporate governance research, is the endogeneity issue of 
the governance variables. It would also be interesting to compare the ownership and control incentives and entrenchment effects of multiple blockholders. These questions have yet to be fully assessed empirically. 


\section{Appendix A.1 \\ Models of Implied Cost of Equity and their Implementation}

$K_{\text {Subscript }}=$ Cost of equity estimate of the model identified in subscript.

$F E P S_{T+t}=\mathrm{I} / \mathrm{B} / \mathrm{E} / \mathrm{S}$ mean earnings forecast for the $\mathrm{t}^{\text {th }}$ year from the estimation year.

$P_{T}=$ Market price at the statistics release date for the estimation year.

$B_{T}=$ Book value per share, $B_{T+i}=B_{T+i-1}+F E P S_{T+i}-D_{T+i}$

$D_{T+i}=F E P S_{T+i}{ }^{*}$ Dividend Payout [firm's dividend payout, where available, otherwise $50 \%$ as in Claus and Thomas (2001)]

Ohlson and Juttner-Nauroth (2005 OJ): Estimating KOJ

$$
K_{O J}=A+\sqrt{A^{2}+\frac{F E P S_{T+1}}{P_{T}}\left[g_{2}-(y-1)\right]},
$$

where: $A=\frac{1}{2}\left[(y-1)+\frac{D_{T+1}}{P_{T}}\right], g_{2}=\frac{F E P S_{T+2}-F E P S_{T+1}}{F E P S_{T+1}}, y=$ a constant which is equal to $1+$ longterm growth rate; the long-term growth rate $(y-1)$ was fixed at the country's inflation premium (in this case a constant equal to $4 \%$ ). Several observations are undefined as the model requires a positive number inside the square root; hence, at this stage we generate 3,039 firm-year $K_{O J}$ estimates for 1,373 firms. ${ }^{26}$

Claus and Thomas (2001 CT): Estimating $K_{C T}$

$$
P_{T}=B_{T}+\frac{F E P S_{T+1}-K_{C T} B_{T}}{\left(1+K_{C T}\right)}+\ldots+\frac{F E P S_{T+5}-K_{C T} B_{T+4}}{\left(1+K_{C T}\right)^{5}}+\frac{\left(F E P S_{T+5}-K_{C T} B_{T+4}\right)\left(1+g_{n}\right)}{\left(K_{C T}-g_{n}\right)\left(1+K_{C T}\right)^{5}}
$$

The forecasts beyond two years are taken as reported where available, otherwise generated based on the five-year consensus growth rate forecast or the average growth in $F E P S_{1}$ to $F E P S_{3}$. The long-term growth rate beyond five years $g_{n}=$ the excess of U.S. T-Bond yield over real risk free rate (approximately $4 \%$ ). Finally, we manually search for $K_{C T}$ that satisfies equation 2 . We exclude observations that do not converge, and $1 \%$ lowest and highest $K_{C T}$ estimators (outliers) and firm-year observations exceeding a growth rate of $200 \%$ (total loss 113 firm-years).

Gebhardt, Lee and Swaminathan (2001 GLS): Estimating KGLS

$$
P_{T}=B_{T}+\frac{F E P S_{T+1}-K_{G L S} B_{T}}{\left(1+K_{G L S}\right)}+\ldots+\frac{F E P S_{T+i}-K_{G L S} B_{T+t-1}}{\left(1+K_{G L S}\right)^{i}}+\frac{F E P S_{T+t+1}-K_{G L S} B_{T+t}}{K_{G L S}\left(1+K_{G L S}\right)^{i}}
$$

$F E P S_{\mathrm{T}+4}$ to $F E P S_{\mathrm{T}+12}$ is forecasted such that $R O I$ gradually (linearly) converges to industry $R O I$ in the $12^{\text {th }}$ year. Industry ROI is estimated as the mean of all firms' ROI at first digit SIC covered in Worldscope from 1994 to 1998 . Growth in earnings after the $12^{\text {th }}$ year is assumed to be zero. We manually search for $K_{G L S}$.

Easton (2004 ES): Estimating $K_{E S}$

$$
P_{T}=\frac{F E P S_{T+2}+K_{E S} D_{T+1}-F E P S_{T+1}}{K_{E S}^{2}}
$$

We manually search for $\mathrm{K}_{E S}$.

${ }^{26}$ The earnings and growth rate forecasts are recorded in the month farthest from the first forecast period (i.e., forecasts made in January for December of the same year). However, if the forecasts made in January do not meet our criteria set out in section 2.1, we choose the forecast recorded in the subsequent month. In all cases, we match the forecast publication date and stock price date. 
Appendix A.2

Variables, Definitions, and Sources

\begin{tabular}{|c|c|c|}
\hline Variable & Definition & Source \\
\hline \multicolumn{3}{|c|}{ Panel A. Firm-Specific Variables } \\
\hline$K_{A V E R A G E}$ & $\begin{array}{l}\text { The dependent variable, our estimate of the firm's implied cost of equity, } \\
\text { estimated as the average of the four different models of implied cost of } \\
\text { equity as described in appendix A.1. }\end{array}$ & Estimated \\
\hline Excess1 & $\begin{array}{l}\text { Ultimate cash flow rights minus ultimate voting rights of the largest } \\
\text { shareholder. }\end{array}$ & $\begin{array}{l}\text { Claessens et al. (2000) } \\
\text { and Faccio and Lang } \\
\text { (2002) }\end{array}$ \\
\hline Presence2 & $\begin{array}{l}\text { A dummy variable set to } 1 \text { for firms with multiple shareholders with at } \\
\text { least } 10 \% \text { of the shares, and } 0 \text { otherwise. }\end{array}$ & $\begin{array}{l}\text { Estimated based on } \\
\text { the data from } \\
\text { Claessens et al. (2000) } \\
\text { and Faccio and Lang } \\
\text { (2002) }\end{array}$ \\
\hline Nowners 2345 & $\begin{array}{l}\text { Number of owners other than the largest shareholder (up to the fifth } \\
\text { shareholder). }\end{array}$ & As above \\
\hline Cont2 & Voting rights (Control) of the second largest shareholder. & $\begin{array}{l}\text { Claessens et al. (2000) } \\
\text { and Faccio and Lang } \\
\text { (2002) }\end{array}$ \\
\hline Cont 2345 & $\begin{array}{l}\text { The sum of the voting rights of the second (Cont2), third (Cont3), fourth } \\
\text { (Cont4), and fifth (Cont5) largest shareholders. }\end{array}$ & $\begin{array}{l}\text { Estimated based on } \\
\text { the data from } \\
\text { Claessens et al. (2000) } \\
\text { and Faccio and Lang } \\
\text { (2002) }\end{array}$ \\
\hline Voting $2 \% 1$ & Cont2 divided by Cont1. & As above \\
\hline Voting $2345 \% 1$ & $($ Cont $2+$ Cont $3+$ Cont $4+$ Cont 5$)$ divided by Cont 1. & As above \\
\hline Hi_Differences & $\begin{array}{l}\text { Hersfindhal index of difference between the voting rights estimated as } \\
\mathrm{Ln}[(\text { Cont } 1-\text { Cont } 2) 2+(\text { Cont } 2 \text {-Cont } 3) 2+(\text { Cont } 3 \text {-Cont } 4) 2+(\text { Cont } 4-\text { Cont } 5) 2] \text {. } \\
\text { This variable is set to zero for firms for which the natural log is undefined } \\
\text { due to equal control of the three largest shareholders. }\end{array}$ & As above \\
\hline Shapley5 & $\begin{array}{l}\text { Shapley value of votes held by small shareholders (i.e. the ocean) divided } \\
\text { by their fraction of votes. }\end{array}$ & As above \\
\hline Cont $2 *$ Family-Family & $\begin{array}{l}\text { Cont } 2 \text { multiplied by the dummy representing } 1 \text { if the identity of the first } \\
\text { shareholder is Family and that of the second shareholder is also Family. }\end{array}$ & As above \\
\hline Cont $2 *$ Family-State & $\begin{array}{l}\text { Cont } 2 \text { multiplied by the dummy representing } 1 \text { if the identity of the first } \\
\text { shareholder is Family and that of the second shareholder is State. }\end{array}$ & As above \\
\hline Cont ${ }^{*}$ Family-Bank & $\begin{array}{l}\text { Cont } 2 \text { multiplied by the dummy representing } 1 \text { if the identity of the first } \\
\text { shareholder is Family and that of the second shareholder is a widely-held } \\
\text { financial institution. }\end{array}$ & As above \\
\hline Analyst Coverage & $\begin{array}{l}\text { I/B/E/S number of analysts that provided estimates of forecasted } \\
\text { earnings per share. }\end{array}$ & $\mathrm{I} / \mathrm{B} / \mathrm{E} / \mathrm{S}$ \\
\hline Market to Book & Market to book value. & Worldscope \\
\hline $\begin{array}{l}\text { Variance of Analyst } \\
\text { Forecasts }\end{array}$ & $\begin{array}{l}\text { Dispersion of estimated first year earnings per share divided by average } \\
\text { earnings forecasts for the first year. }\end{array}$ & $\mathrm{I} / \mathrm{B} / \mathrm{E} / \mathrm{S}$ \\
\hline Volatility & $\begin{array}{l}\text { Coefficient of variation of annual stock prices, estimated as standard } \\
\text { deviation of annual stock prices divided by the average of annual stock } \\
\text { prices. }\end{array}$ & $\begin{array}{l}\text { Worldscope / } \\
\text { Estimated }\end{array}$ \\
\hline Leverage & Total book value of debt to market value of equity + book value of debt. & Worldscope \\
\hline Growth & $\begin{array}{l}\text { I/B/E/S five-year growth rate (averaged for all available forecasts for a } \\
\text { given firm year, estimated using three years of earnings where not } \\
\text { available). }\end{array}$ & $\mathrm{I} / \mathrm{B} / \mathrm{E} / \mathrm{S}$ \\
\hline
\end{tabular}




\begin{tabular}{llc}
\hline Panel B. Country- and Industry-Specific Variables & \\
\hline $\begin{array}{l}\text { Industry Cost of } \\
\text { Capital }\end{array}$ & $\begin{array}{l}\text { Industry risk premium estimated as the average of the implied cost of } \\
\text { equity estimates for each constituent of the industry. }\end{array}$ & $\begin{array}{c}\text { Estimated as mean } \\
\mathrm{K}_{A V E R A G E} \text { at first digit } \\
\text { Ln(100-Country }\end{array}$ \\
$\begin{array}{ll}\text { SIC code } \\
\text { Rating) }\end{array}$ & $\begin{array}{l}\text { The country credit ratings measure country's political, financial } \\
\text { economic risk exposure. }\end{array}$ & Institutional \\
\end{tabular}




\section{References}

Almeida, H. and D. Wolfenzon, 2006, A Theory of Pyramidal Ownership and Family Business Groups, Journal of Finance 61, 2637-2680.

Anderson D., D. Reeb, and S. Mansi, 2003, Founding-Family Ownership and the Agency Cost of Debt, Journal of Financial Economics 68, 263-285.

Attig, N., W.-M. Fong, L. Lang, and Y. Gadhoum, 2006, Effects of Large Shareholding on Information Asymmetry and Stock Liquidity, Journal of Banking and Finance 30, 28752892.

Bansal, R. and M. Dahlquist, 2002, Expropriation Risk and Return in Global Equity Markets, Working Paper, Duke University.

Barontini, R. and L. Caprio, 2005, The Effect of Ownership Structure and Family Control on Firm Value and Performance: Evidence from Continental Europe, Working Paper, ECGI.

Bekaert, G. and C. Harvey, 1995, Time-Varying World Market Integration, Journal of Finance 50, 403-444.

Bennedsen, M. and D. Wolfenzon, 2000, The Balance of Power in Closely Held Corporations, Journal of Financial Economics 58, 113-139.

Bloch, F. and U. Hege, 2001, Multiple Large Shareholders and Control Contests, Mimeo, HEC.

Botosan, C., 1997, Disclosure Level and the Cost of Equity Capital, The Accounting Review 72, 323-349.

Botosan, C. and M. Plumlee, 2005, Assessing Alternative Proxies for Expected Risk Premium, The Accounting Review 80, 21-53.

Capstaff, J., K. Paudyal, and W. Rees, 2001, A Comparative Analysis of Earnings Forecasts in Europe, Journal of Business Finance $\mathcal{E}$ Accounting 28, 531-562.

Claessens, S., S. Djankov, J. Fan, and L. Lang, 2000, The Separation of Ownership and Control in East Asian Corporations, Journal of Financial Economics 58, 81-112.

Claessens, S., S. Djankov, J. Fan, and L. Lang, 2002, Disentangling the Incentive and Entrenchment Effects of Large Shareholdings, Journal of Finance 57, 2741-2771.

Claus, J. and J. Thomas, 2001, Equity Premia as Low as Three Percent? Evidence from Analysts' Earnings Forecasts for Domestic and International Stock Markets, Journal of Finance 56, 1629-1666.

Daske, H., 2006, Economic Benefits of Adopting IFRS or US-GAAP - Have the Expected Costs of Equity Capital Really Decreased?, Journal of Business Finance $\mathcal{E}$ Accounting 33, 329-373.

Dhaliwal, D., S. Eheitzman, and O. Li, 2006, Taxes, Leverage, and the Cost of Equity Capital, Journal of Accounting Research 44, 691-723.

Dhaliwal, D., L. Krull, O. Li, and W. Moser, 2005, Dividend Taxes and Implied Cost of Equity Capital, Journal of Accounting Research 43, 675-708. 
Dyck, A. and L. Zingales, 2004, Control Premiums and the Effectiveness of Corporate Governance Systems, Journal of Applied Corporate Finance 16, 51-72.

Easley, D. and M. O'Hara, 2004, Information and the Cost of Capital, Journal of Finance 59, 15531583.

Easton, P., 2004, PE Ratios, PEG Ratios, and Estimating the Implied Expected Rate of Return on Equity Capital, The Accounting Review 79, 73-95.

Easton, P. and S. Monahan, 2005, An Evaluation of Accounting Based Measures of Expected Returns, The Accounting Review 80, 501-538.

El Ghoul, S., O. Guedhami, C. Lennox, and J. A. Pittman, 2007, Ownership Structure, Agency Problems, and Auditor Choice: Evidence from Western European Firms, Working Paper, Hong Kong University of Science and Technology and University of South Carolina.

Elton, E., 1999, Expected Return, Realized Return, and Asset Pricing Tests, Journal of Finance 54, $1199-1220$.

Erb, C., C. Harvey, and T. Viskanta, 1996, Political Risk, Economic Risk and Financial Risk, Financial Analyst Journal 52, 28-46.

Faccio, M. and L. Lang, 2002, The Ultimate Ownership of Western European Corporations, Journal of Financial Economics 65, 365-395.

Faccio, M., L. Lang, and L. Young, 2001, Dividends and Expropriation, American Economic Review 91, 54-78.

Fama, E. and K. French, 1992, The Cross Sections of Expected Stock Returns, The Journal of Finance 47, 427-466.

Fama, E. and K. French, 1993, Common Risk Factors in the Returns on Stocks and Bonds, Journal of Financial Economics 33, 3-56.

Fama, E. and K. French, 1997, Industry Costs of Equity, Journal of Financial Economics 43, 153-194.

Fama, E. and K. French, 2004, The Capital Asset Pricing Model: Theory and Evidence, Journal of Economic Perspectives 18, 25-46.

Fan, J. and T. Wong, 2002, Corporate Ownership Structure and the Informativeness of Accounting Earnings in East Asia, Journal of Accounting and Economics 33, 401-425.

Fan, J. and T. Wong, 2005, Do External Auditors Perform a Corporate Governance Role in Emerging Markets? Evidence from East Asia, Journal of Accounting Research 43, 1-38.

Feltham, G. and J. Ohlson, 1995, Valuation and Clean Surplus Accounting for Operating and Financial Activities, Contemporary Accounting Research 11, 689-731.

Francis, J., I. Khurana, and R. Pereira, 2005, Disclosure Incentives and Effect on Cost of Capital around the World, The Accounting Review 80, 1125-1162.

Francis, J., R. Lafond, P. Olessen, and K. Schipper, 2004, Cost of Equity and Earnings Attributes, The Accounting Review 79, 967-1010. 
Gebhardt, W., C. Lee, and B. Swaminathan, 2001, Towards an Implied Cost of Capital, Journal of Accounting Research 39, 135-176.

Gode, D. and P. Mohanram, 2003, Inferring the Cost of Capital Using the Ohlson-Juettner Model, Review of Accounting Studies 8, 399-431.

Gomes, A. and W. Novaes, 2005, Sharing of Control versus Monitoring as Corporate Governance Mechanisms, Working Paper, Wharton School.

Guay, W., S. Kothari, and S. Shu, 2005, Properties of implied cost of capital using analysts' forecasts, MIT Sloan Working Paper No. 4422-03.

Guedhami, O. and D. Mishra, 2008, Excess Control, Corporate Governance, and Implied Cost of Equity: International Evidence, Financial Review, forthcoming.

Hail, L. and C. Leuz, 2006, International Differences in Cost of Equity Capital: Do Legal Institutions and Securities Regulations Matter?, Journal of Accounting Research 44, 485531.

Hamada, R., 1969, Portfolio Analysis, Market Equilibrium, and Corporation Finance, Journal of Finance 24, 13-31.

Harvey, C., 1995, Predictable Risk and Returns in Emerging Markets, Review of Financial Studies $8,773-816$.

Harvey, C., 2000, The Drivers of Expected Returns in International Markets, Emerging Markets Quarterly 4, 1-17.

Haw, I.-M., B. Hu, L.-S. Hwang, and W. Wu, 2004, Ultimate Ownership, Income Management, and Legal and Extra-Legal Institutions, Journal of Accounting Research 42, 423-462.

Hughes, J.S., J. Liu, and J. Liu, 2006, Information Asymmetry, Diversification, and Cost of Capital, The Accounting Review 82, 705-729.

Kahn, C. and A. Winton, 1998, Ownership Structure, Speculation, and Shareholder Intervention, Journal of Finance 53, 99-129.

La Porta, R., F. Lopez-de-Silanes, and A. Shleifer, 1999, Corporate Ownership around the World, Journal of Finance 54, 471-517.

La Porta, R., F. Lopez-de-Silanes, and A. Shleifer, 2006, What Works in Securities Laws?, Journal of Finance 61, 1-32.

La Porta, R., F. Lopez-de-Silanes, A. Shleifer, R. W. Vishny, 1997, Legal determinants of external finance, Journal of Finance 52, 1131-1150.

La Porta, R., F. Lopez-de-Silanes, A. Shleifer, and R. W. Vishny, 1998, Law and Finance, Journal of Political Economy 106, 1113-1155.

La Porta, R., F. Lopez-de-Silanes, A. Shleifer, and R. W. Vishny, 2002, Investor Protection and Corporate Valuation, Journal of Finance 57, 1147-1170.

Laeven, L. and R. Levine, 2007, Complex Ownership Structures and Corporate Valuations, Review of Financial Studies, forthcoming. 
Lambert R., Leuz C., and R. Verrecchia, 2007, Accounting Information, Disclosure and the Cost of Capital, Journal of Accounting Research 45, 385-420.

Lee, C., D. Ng, and B. Swaminathan, 2004, International Asset Pricing: Evidence from the Cross Section of Implied Cost of Capital, Working Paper, Cornell University.

Lintner, J., 1965, The Valuation of Risk Assets and the Selection of Risky Investments in Stock Portfolios and Capital Budgets, Review of Economics and Statistics 47, $13-37$.

Maury, B., 2006, Family Ownership and Firm Performance: Empirical Evidence from Western European Corporations, Journal of Corporate Finance 12, 321-341.

Maury, B. and A. Pajuste, 2005, Multiple Controlling Shareholders and Firm Value, Journal of Banking and Finance 29, 1813-1834.

Megginson, W. L. and J. N. Netter, 2001, From State to Market: A Survey of Empirical Studies on Privatization, Journal of Economic Literature 39, 321-389.

Mikhail, M., B. Walther, and R. Willis, 2004, Earnings Surprises and the Cost of Equity Capital, Journal of Accounting Auditing and Finance 9, 491-514.

Milnor, J.W. and L.S. Shapley, 1978. Values of Large Games: II. Oceanic Games, Mathematics of Operations Research 3, 290-307.

Mishra, D. and T. O'Brien, 2005, Risk and Ex-Ante Cost of Equity Estimates of Emerging Market Firms, Emerging Markets Review 6, 107-120.

Modigliani, F. and M. Miller, 1958, The Cost of Capital, Corporation Finance and the Theory of Investment, American Economic Review 48, 261-297.

Ohlson, J., 1995, Earnings, Book Value, and Dividends in Security Valuation, Contemporary Accounting Research 11, 661-687.

Ohlson, J. and B. Juettner-Nauroth, 2005, Expected EPS and EPS Growth as Determinants of Value, Review of Accounting Studies 10, 349-365.

Pagano, M. and A. Roell, 1998, The Choice of Stock Ownership Structure: Agency Costs, Monitoring, and the Decision to Go Public, Quarterly Journal of Economics 113, 187-225.

Pound, John, 1988, Proxy Contests and the Efficiency of Shareholder Oversight, Journal of Financial Economics 20, 237-65.

Sengupta P., 1998, Corporate Disclosure Quality and the Cost of Debt, The Accounting Review 73, 459-474.

Sharpe, W., 1964, Capital Asset Prices: A Theory of Market Equilibrium under Conditions of Risk, Journal of Finance 19, 425-442.

Villalonga, B. and A. Amit, 2006, How do Family Ownership, Control, and Management Affect Firm Value?, Journal of Financial Economics 80, 385-417.

Wang, D., 2006, Founding Family Ownership and Earnings Quality, Journal of Accounting Research 44, 619-656. 
Winton, A., 1993, Limitation of Liability and the Ownership Structure of the Firm, Journal of Finance 48, 487-512.

Zingales, L., 1994, The Value of the Voting Right: A Study of the Milan Stock Exchange Experience, Review of Financial Studies 7, 125-148.

Zwiebel, J., 1995, Block Investment and Partial Benefits of Corporate Control, Review of Economic Studies 62, 161-185. 
Table 1

Summary of Implied Cost of Equity

\begin{tabular}{|c|c|c|c|c|c|c|}
\hline \multicolumn{7}{|c|}{ Panel A: Implied Cost of Equity by Country } \\
\hline Country & $\mathrm{N}$ & Mean & St.Dev. & Q1 & Median & Q3 \\
\hline Austria & 38 & $12.5 \%$ & $3.9 \%$ & $9.3 \%$ & $12.3 \%$ & $15.3 \%$ \\
\hline Belgium & 70 & 12.6 & 4.9 & 9.4 & 11.5 & 13.9 \\
\hline Finland & 45 & 17.0 & 7.7 & 13.1 & 14.9 & 18.4 \\
\hline France & 183 & 12.6 & 5.4 & 9.0 & 10.6 & 15.2 \\
\hline Germany & 94 & 10.0 & 2.6 & 8.2 & 10.0 & 11.6 \\
\hline Hong Kong & 260 & 15.9 & 6.3 & 11.4 & 14.4 & 19.4 \\
\hline Indonesia & 89 & 14.3 & 5.7 & 10.2 & 13.2 & 17.3 \\
\hline Ireland & 13 & 10.6 & 2.5 & 8.9 & 9.6 & 12.3 \\
\hline Italy & 46 & 12.8 & 5.2 & 8.9 & 11.2 & 15.8 \\
\hline Malaysia & 201 & 9.4 & 2.6 & 7.8 & 8.8 & 10.5 \\
\hline Norway & 57 & 13.4 & 3.7 & 11.1 & 13.1 & 16.0 \\
\hline Philippines & 124 & 15.1 & 6.0 & 10.6 & 13.5 & 17.9 \\
\hline Portugal & 54 & 13.9 & 5.8 & 9.9 & 12.3 & 16.3 \\
\hline Singapore & 170 & 10.3 & 3.3 & 8.1 & 9.7 & 11.9 \\
\hline South Korea & 127 & 15.2 & 6.1 & 11.1 & 13.6 & 18.0 \\
\hline Spain & 54 & 13.1 & 4.5 & 9.7 & 12.3 & 14.6 \\
\hline Sweden & 79 & 13.1 & 3.5 & 10.5 & 12.5 & 15.5 \\
\hline Switzerland & 78 & 11.8 & 3.9 & 9.2 & 10.9 & 14.0 \\
\hline Taiwan & 34 & 10.4 & 3.2 & 8.3 & 9.4 & 11.7 \\
\hline Thailand & 97 & 12.4 & 4.7 & 9.3 & 11.1 & 14.1 \\
\hline UK & 605 & 10.5 & 3.1 & 8.8 & 10.0 & 11.7 \\
\hline All & 2,518 & 12.3 & 5.0 & 9.1 & 11.0 & 14.2 \\
\hline \multicolumn{7}{|c|}{ Panel B: Pearson Correlation Coefficients between Implied Cost of Capital Estimates } \\
\hline & $K_{O J}$ & $K_{E S}$ & $K_{C T}$ & $K_{G L S}$ & & \\
\hline $\mathrm{K}_{E S}$ & 0.99 & & & & & \\
\hline $\mathrm{K}_{\mathrm{CT}}$ & 0.62 & 0.66 & & & & \\
\hline $\mathrm{K}_{G L S}$ & 0.44 & 0.48 & 0.65 & & & \\
\hline $\mathrm{K}_{A V E R A G E}$ & 0.89 & 0.92 & 0.86 & 0.75 & & \\
\hline \multicolumn{7}{|c|}{ Panel C: Descriptive Statistics for Implied Cost of Equity Models } \\
\hline Variable & $\mathrm{N}$ & Mean & St. Dev. & Q1 & Median & Q3 \\
\hline$K_{O J}$ & 2,518 & $14.9 \%$ & $5.9 \%$ & $11.2 \%$ & $13.6 \%$ & $17.2 \%$ \\
\hline$K_{E S}$ & 2,518 & 13.8 & 5.7 & 10.3 & 12.6 & 16.0 \\
\hline$K_{C T}$ & 2,518 & 12.2 & 6.2 & 8.6 & 10.4 & 13.3 \\
\hline$K_{G L S}$ & 2,518 & 8.4 & 5.7 & 4.4 & 6.6 & 10.7 \\
\hline$K_{A V E R A G E}$ & 2,518 & 12.3 & 5.0 & 9.1 & 11.0 & 14.2 \\
\hline \multicolumn{7}{|c|}{$\begin{array}{l}\text { This table reports statistical properties for the cost of equity estimates of four models individually, and our } \\
\text { estimate of the firm's ultimate cost of equity capital for } 2,518 \text { firm-year observations representing firms with at } \\
\text { least one shareholder with } 10 \% \text { or more voting rights, from } 8 \text { East Asian and } 13 \text { Western European countries } \\
\text { over the period } 1995-1997 . K_{A V E R A G E} \text { is the proxy for the firm's ultimate cost of capital, estimated as the equally } \\
\text { weighted average of } K_{O J,} K_{E S,} K_{C T} \text {, and } K_{G L S,} \text { where the latter respectively represent implied cost of equity } \\
\text { estimates of Ohlson and Juttener-Narouth (2000), Easton (2004), Claus and Thomas (2001), and Gebhardt, Lee, } \\
\text { and Swaminathan (2001) models. Appendix A.2 reports detailed definitions and data sources for all variables. }\end{array}$} \\
\hline
\end{tabular}


Table 2

Descriptive Statistics for the Explanatory Variables

\begin{tabular}{|c|c|c|c|c|c|c|}
\hline Variable & $\mathrm{N}$ & Mean & St. Dev. & Q1 & Median & Q3 \\
\hline Excess1 & 2,518 & 4.85 & 8.28 & 0.00 & 0.00 & 8.00 \\
\hline Presence2 & 2,518 & 0.44 & 0.50 & 0.00 & 0.00 & 1.00 \\
\hline Nowners 2345 & 2,518 & 0.85 & 1.03 & 0.00 & 1.00 & 1.00 \\
\hline Cont2 & 1,293 & 13.81 & 6.92 & 10.00 & 11.08 & 19.90 \\
\hline Cont2345 & 1,293 & 19.64 & 12.70 & 10.30 & 15.74 & 25.00 \\
\hline Voting2\% 1 & 2,518 & 0.27 & 0.33 & 0.00 & 0.10 & 0.50 \\
\hline Voting $2345 \% 1$ & 2,518 & 0.39 & 0.54 & 0.00 & 0.12 & 0.68 \\
\hline Hi_Differences & 2,518 & 6.22 & 1.51 & 5.33 & 6.29 & 7.41 \\
\hline Shapley5 & 2,518 & 0.67 & 0.40 & 0.43 & 0.88 & 0.95 \\
\hline Analyst Coverage & 2,518 & 11.46 & 7.58 & 5.00 & 10.00 & 15.00 \\
\hline Market to Book & 2,518 & 2.65 & 5.25 & 1.07 & 1.72 & 2.95 \\
\hline Variance of Analyst Forecasts & 2,518 & 0.17 & 0.35 & 0.06 & 0.10 & 0.18 \\
\hline Variance & 2,518 & 0.41 & 0.24 & 0.25 & 0.36 & 0.52 \\
\hline Leverage (\%) & 2,518 & 35.05 & 22.76 & 17.50 & 33.45 & 50.42 \\
\hline Growth & 2,518 & 0.20 & 0.30 & 0.10 & 0.15 & 0.22 \\
\hline \multicolumn{7}{|c|}{$\begin{array}{l}\text { This table reports descriptive statistics on all variables used in the regressions. The sample includes 2,518 firm- } \\
\text { year observations from } 8 \text { East Asian and } 13 \text { Western European countries over the period 1995-1997. We obtain } \\
\text { ownership data from Claessens et al. (2000) and Faccio and Lang (2002). The sample includes only those firms } \\
\text { that have at least one shareholder with 10\% or more voting rights. Appendix A.2 reports detailed definitions } \\
\text { and data sources for all variables. }\end{array}$} \\
\hline
\end{tabular}


Table 3

Descriptive Statistics for the Distribution of the Five Largest Shareholders

\begin{tabular}{lcccc}
\hline Panel A: Distribution of Shareholder Type & & & \\
\hline Shareholder & Family & State & Bank & Other \\
\hline $1^{\text {st largest }}$ & $43.5 \%$ & $9.4 \%$ & $12.3 \%$ & $34.8 \%$ \\
$2^{\text {nd }}$ largest & $13.2 \%$ & $5.1 \%$ & $15.1 \%$ & $66.6 \%$ \\
$3^{\text {rd largest }}$ & $4.5 \%$ & $1.6 \%$ & $8.5 \%$ & $85.3 \%$ \\
$4^{\text {th }}$ largest & $1.4 \%$ & $0.3 \%$ & $3.2 \%$ & $95.2 \%$ \\
$5^{\text {th }}$ largest & $0.2 \%$ & $0.4 \%$ & $1.2 \%$ & $98.2 \%$ \\
\hline
\end{tabular}

Panel B: Distribution of Shareholder Type when the Coalition of the First and Second Largest Shareholders is Family-Family Type $(6.2 \%)$

\begin{tabular}{lcccc}
\hline Shareholder & Family & State & Bank & Other \\
\hline $3^{\text {rd }}$ largest & $20.0 \%$ & $4.0 \%$ & $10.7 \%$ & $65.3 \%$ \\
$4^{\text {th }}$ largest & $2.7 \%$ & $0.0 \%$ & $8.0 \%$ & $89.3 \%$ \\
$5^{\text {th }}$ largest & $0.0 \%$ & $0.0 \%$ & $0.0 \%$ & $100.0 \%$ \\
\hline
\end{tabular}

Panel C: Distribution of Shareholder Type when the Coalition of the First and Second Largest Shareholders is Family-Bank Type (6.9\%)

\begin{tabular}{lcccc}
\hline Shareholder & Family & State & Bank & Other \\
\hline $3^{\text {rd }}$ largest & $9.8 \%$ & $4.9 \%$ & $26.8 \%$ & $58.5 \%$ \\
$4^{\text {th }}$ largest & $6.1 \%$ & $0.0 \%$ & $11.0 \%$ & $82.9 \%$ \\
$5^{\text {th }}$ largest & $1.2 \%$ & $2.4 \%$ & $3.7 \%$ & $92.7 \%$ \\
\hline
\end{tabular}

Panel D: Distribution of Shareholder Type when the Coalition of the First and Second Largest Shareholders is Family-State Type (3.6\%)

\begin{tabular}{lcccc}
\hline Shareholder & Family & State & Bank & Other \\
\hline $3^{\text {rd }}$ largest & $7.3 \%$ & - & $41.5 \%$ & $51.2 \%$ \\
$4^{\text {th }}$ largest & $7.3 \%$ & - & $14.6 \%$ & $78.1 \%$ \\
$5^{\text {th }}$ largest & $0.00 \%$ & - & $7.3 \%$ & $92.7 \%$ \\
\hline
\end{tabular}

This table reports descriptive statistics on the distribution of the types of the five largest shareholders. Panel B reports the distribution of the types of the three largest shareholders beyond the family-family coalition of the two largest shareholders. Panel C and Panel D report similar statistics for the family-bank and family-state coalitions, respectively. Ownership data is from Claessens et al. (2000) and Faccio and Lang (2002). 
Table 4

Correlation between the Explanatory Variables

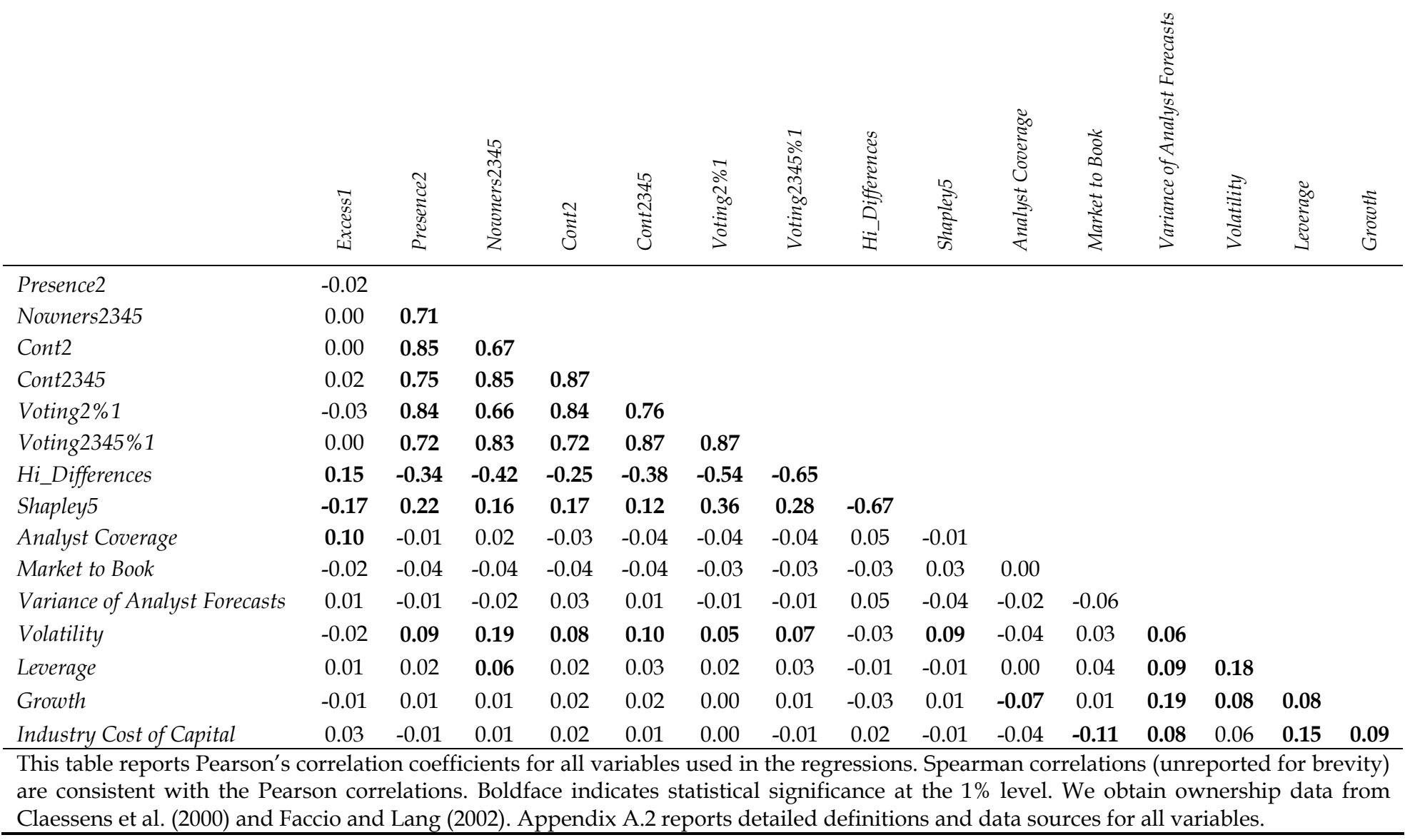


Table 5

The Impact of Multiple Large Shareholders on the Cost of Equity

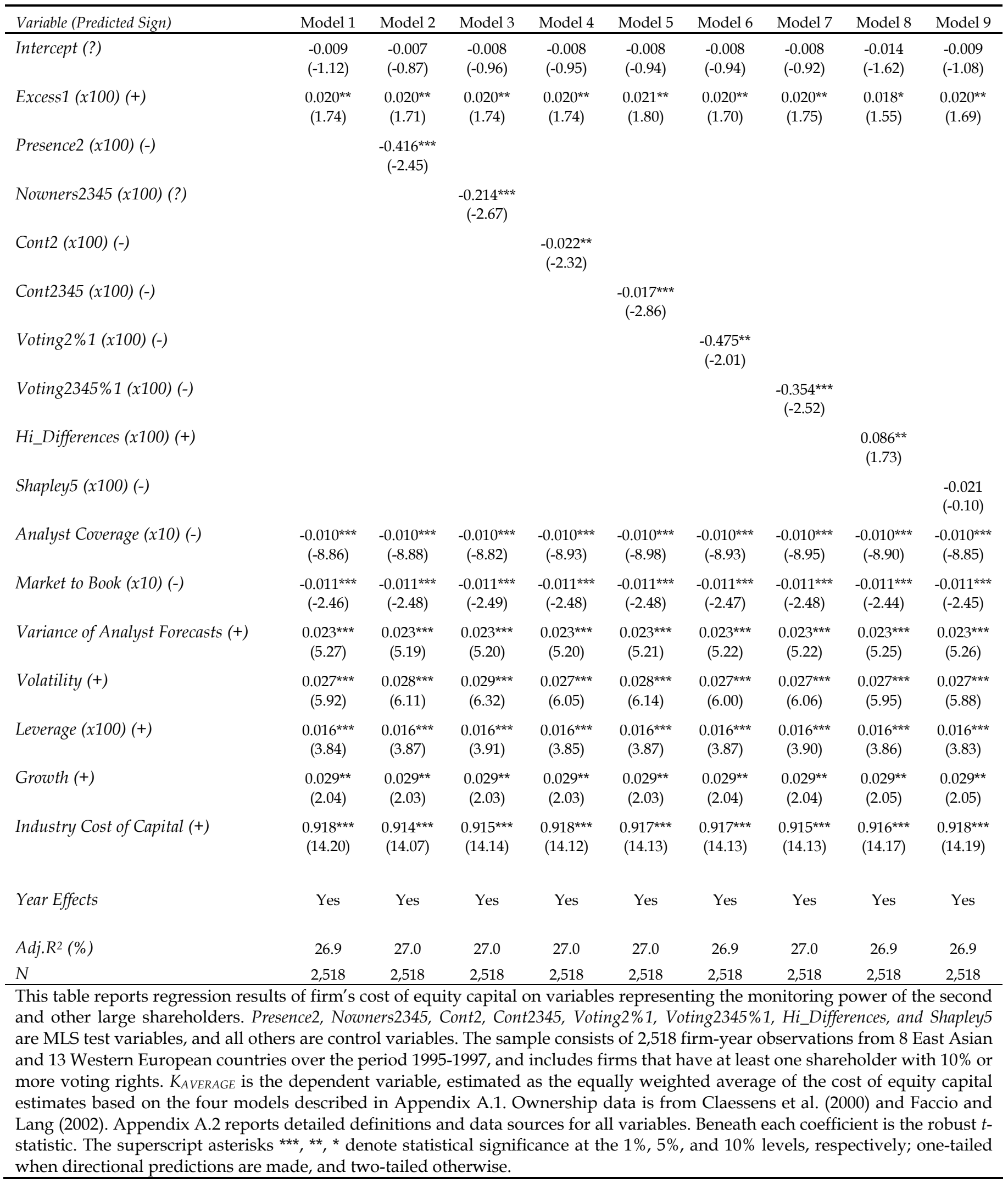


Table 6

Cost of Equity and Identity of the Second Largest Shareholder

\begin{tabular}{|c|c|c|c|}
\hline Variable (Predicted Sign) & Model 1 & Model 2 & Model 3 \\
\hline Intercept (?) & $\begin{array}{l}-0.008 \\
(-0.95)\end{array}$ & $\begin{array}{l}-0.009 \\
(-1.06)\end{array}$ & $\begin{array}{l}-0.008 \\
(-0.92)\end{array}$ \\
\hline Excess1 $(x 100)(+)$ & $\begin{array}{c}0.020^{* *} \\
(1.76)\end{array}$ & $\begin{array}{c}0.020^{* *} \\
(1.76)\end{array}$ & $\begin{array}{c}0.020^{* *} \\
(1.72)\end{array}$ \\
\hline Cont2 (x100) (-) & $\begin{array}{c}-0.027^{* * *} \\
(-2.76)\end{array}$ & $\begin{array}{c}-0.016^{* *} \\
(-1.67)\end{array}$ & $\begin{array}{c}-0.023^{* * *} \\
(-2.43)\end{array}$ \\
\hline Cont ${ }^{*}$ Family-Family (x100) (+) & $\begin{array}{c}0.041^{* *} \\
(1.98)\end{array}$ & & \\
\hline Cont $2{ }^{*}$ Family-State $(x 100)(+)$ & & $\begin{array}{c}-0.106^{* * *} \\
(-4.50)\end{array}$ & \\
\hline Cont2*Family-Bank (x100) (-) & & & $\begin{array}{l}0.000 \\
(0.62)\end{array}$ \\
\hline Analyst Coverage (x10) (-) & $\begin{array}{c}-0.010^{* * *} \\
(-8.91)\end{array}$ & $\begin{array}{c}-0.010^{* * *} \\
(-8.67)\end{array}$ & $\begin{array}{c}-0.010^{* * *} \\
(-8.95)\end{array}$ \\
\hline Market to Book (x10) (-) & $\begin{array}{c}-0.011^{* * *} \\
(-2.48)\end{array}$ & $\begin{array}{c}-0.011^{* * *} \\
(-2.48)\end{array}$ & $\begin{array}{c}-0.011^{* * *} \\
(-2.47)\end{array}$ \\
\hline Variance of Analyst Forecasts (+) & $\begin{array}{c}0.023^{* * *} \\
(5.20)\end{array}$ & $\begin{array}{c}0.023^{* * *} \\
(5.20)\end{array}$ & $\begin{array}{c}0.023^{* * *} \\
(5.20)\end{array}$ \\
\hline Volatility (+) & $\begin{array}{c}0.027^{* \star *} \\
(5.97)\end{array}$ & $\begin{array}{c}0.027^{* * *} \\
(6.06)\end{array}$ & $\begin{array}{c}0.027^{* * *} \\
(5.92)\end{array}$ \\
\hline Leverage $(x 100)(+)$ & $\begin{array}{c}0.016^{* * *} \\
(3.88)\end{array}$ & $\begin{array}{c}0.016^{* * *} \\
(3.79)\end{array}$ & $\begin{array}{c}0.016^{* * *} \\
(3.83)\end{array}$ \\
\hline Growth (+) & $\begin{array}{l}0.029^{* *} \\
(2.03)\end{array}$ & $\begin{array}{l}0.029^{* *} \\
(2.03)\end{array}$ & $\begin{array}{c}0.029^{* *} \\
(2.03)\end{array}$ \\
\hline Industry Cost of Capital (+) & $\begin{array}{c}0.919^{* * *} \\
(14.11)\end{array}$ & $\begin{array}{c}0.925^{* * *} \\
(14.21)\end{array}$ & $\begin{array}{c}0.918^{* * *} \\
(14.11)\end{array}$ \\
\hline Year Effects & Yes & Yes & Yes \\
\hline $\operatorname{Adj} . R^{2}(\%)$ & 27.05 & 27.25 & 26.97 \\
\hline$N$ & 2,518 & 2,518 & 2,518 \\
\hline
\end{tabular}

This table reports regression results of firm's cost of equity capital on variables representing the identity of the two largest shareholders and voting rights of the second large shareholder. Cont2*Family-Family, Cont ${ }^{*}$ Family-State, and Cont ${ }^{*}$ Family-Bank are test variables, where the largest shareholder is a family and the second large shareholder is a family, state, or widely-held bank, respectively. All others are control variables. The sample consists of 2,518 firm-year observations from 8 East Asian and 13 Western European countries over the period 1995-1997, and includes firms that have at least one shareholder with $10 \%$ or more voting rights. $K_{A V E R A G E}$ is the dependent variable, estimated as the equally weighted average of the cost of equity capital estimates based on the four models described in Appendix A.1. Ownership data is from Claessens et al. (2000) and Faccio and Lang (2002). Appendix A.2 reports detailed definitions and data sources for all variables. Beneath each coefficient is the robust $t$-statistic. The superscript asterisks ***, **, * denote statistical significance at the $1 \%, 5 \%$, and $10 \%$ levels, respectively; one-tailed when directional predictions are made, and twotailed otherwise. 
Table 7

The Impact of Multiple Large Shareholders on the Cost of Equity: Regional Analysis

\begin{tabular}{|c|c|c|c|c|}
\hline \multirow{2}{*}{$\begin{array}{l}\text { Region } \\
\text { Variable (Predicted Sign) }\end{array}$} & \multicolumn{2}{|c|}{ Asia } & \multicolumn{2}{|c|}{ Europe } \\
\hline & $\begin{array}{l}\text { Coefficient } \\
(t \text {-statistic) }\end{array}$ & Adj.R $R^{2}(\%)$ & $\begin{array}{l}\text { Coefficient } \\
(t \text {-statistic) }\end{array}$ & Adj.R2 (\%) \\
\hline Presence2 (x100) (-) & $\begin{array}{c}-1.287^{* * *} \\
(-4.29)\end{array}$ & 26.9 & $\begin{array}{l}0.268 \\
(1.41)\end{array}$ & 34.16 \\
\hline Nowners2345 (x100) (?) & $\begin{array}{c}-0.711^{* * *} \\
(-5.50)\end{array}$ & 27.4 & $\begin{array}{l}0.117 \\
(1.12)\end{array}$ & 34.13 \\
\hline Cont2 (x100) (-) & $\begin{array}{c}-0.097^{* * *} \\
(-5.26)\end{array}$ & 27.2 & $\begin{array}{l}0.016 \\
(1.46)\end{array}$ & 34.18 \\
\hline Cont2345 (x100) (-) & $\begin{array}{c}-0.075^{\star * *} \\
(-6.13)\end{array}$ & 27.8 & $\begin{array}{l}0.008 \\
(1.22)\end{array}$ & 34.14 \\
\hline Voting2\%1 (x100) (-) & $\begin{array}{c}-1.905^{\star * *} \\
(-3.88)\end{array}$ & 26.5 & $\begin{array}{l}0.319 \\
(1.28)\end{array}$ & 34.14 \\
\hline Voting2345\%1 (x100) (-) & $\begin{array}{c}-1.450^{* * *} \\
(-4.87)\end{array}$ & 26.9 & $\begin{array}{l}0.168 \\
(1.16)\end{array}$ & 34.13 \\
\hline Hi_Differences $(x 100)(+)$ & $\begin{array}{l}0.033 \\
(0.25)\end{array}$ & 25.6 & $\begin{array}{l}0.067^{*} \\
(1.33)\end{array}$ & 34.15 \\
\hline Shapley5 (x100) (-) & $\begin{array}{l}0.498 \\
(1.27)\end{array}$ & 25.7 & $\begin{array}{c}-0.384^{* *} \\
(-1.73)\end{array}$ & 34.21 \\
\hline Cont2_Family-Family $(x 100)(+)$ & $\begin{array}{l}0.047^{*} \\
(1.54)\end{array}$ & 25.7 & $\begin{array}{l}-0.009 \\
(-0.44)\end{array}$ & 34.08 \\
\hline Cont2_Family-State $(x 100)(+)$ & $\begin{array}{c}-0.168^{* * *} \\
(-7.79)\end{array}$ & 26.7 & $\begin{array}{c}0.055^{* * *} \\
(2.59)\end{array}$ & 34.10 \\
\hline Cont2_Family-Bank (x100) (-) & $\begin{array}{c}-0.092^{* * *} \\
(-2.72)\end{array}$ & 25.9 & $\begin{array}{c}0.106^{* * *} \\
(2.65)\end{array}$ & 34.5 \\
\hline$N$ & 1,102 & & 1,416 & \\
\hline $\begin{array}{l}\text { This table reports, for East Asia } \\
\text { and } 6 \text { (Models } 1 \text { through } 3 \text { ). Pr } \\
\text { Shapley5, Cont2*Family-Family, } \\
\text { variables, the largest sharehold } \\
\text { bank, respectively. Each row re } \\
\text { year effects. The subsamples co } \\
\text { year observations from } 13 \text { West } \\
\text { least one shareholder with } 10 \\
\text { equally weighted average of th } \\
\text { A.1. Ownership data is from C } \\
\text { definitions and data sources fo } \\
\text { asterisks } * * *, * *, * \text { denote statis } \\
\text { directional predictions are mad }\end{array}$ & $\begin{array}{l}\text { Europe, result } \\
\text { rs } 2345, \text { Cont2 } \\
\text { tate, and Cont } \\
\text { and the secon } \\
\text { ssion includin } \\
\text { irm-year obse } \\
\text { countries ove } \\
\text { ting rights. } \\
\text { capital estim } \\
\text { (2000) and Fa } \\
\text { Beneath eac } \\
\text { ce at the } 1 \% \\
\text { ed otherwise. }\end{array}$ & $\begin{array}{l}\text { m tests repli } \\
\text { nt2345, Votin } \\
\text { mily-Bank are } \\
\text { ge sharehol } \\
\text { control vari } \\
\text { ions from } 8 \\
\text { period } 1995 \\
\text { aGE is the de } \\
\text { based on the } \\
\text { and Lang (2 } \\
\text { efficient is } t \text { l } \\
\text { and } 10 \% 1\end{array}$ & $\begin{array}{l}\text { g Tables } 5(\mathrm{M} \\
\text { 1, Voting } 2345 \\
\text { variables. In } \\
\text { a family, sta } \\
\text { used in Tabl } \\
\text { Asian countri } \\
\text {, and include } \\
\text { dent variable } \\
\text { models desc } \\
\text { Appendix A } \\
\text { bust } t \text {-statisti } \\
\text { respectively }\end{array}$ & $\begin{array}{l}\text { s } 2 \text { through 9) } \\
\text { Hi_Differences, } \\
\text { last three test } \\
r \text { widely-held } \\
\text { and } 6 \text { besides } \\
\text { ad } 1,416 \text { firm- } \\
\text { s that have at } \\
\text { mated as the } \\
\text { in Appendix } \\
\text { ports detailed } \\
\text { he superscript } \\
\text { e-tailed when }\end{array}$ \\
\hline
\end{tabular}


Table 8

Sensitivity Tests 1: Alternative Measures of the Cost of Equity Capital

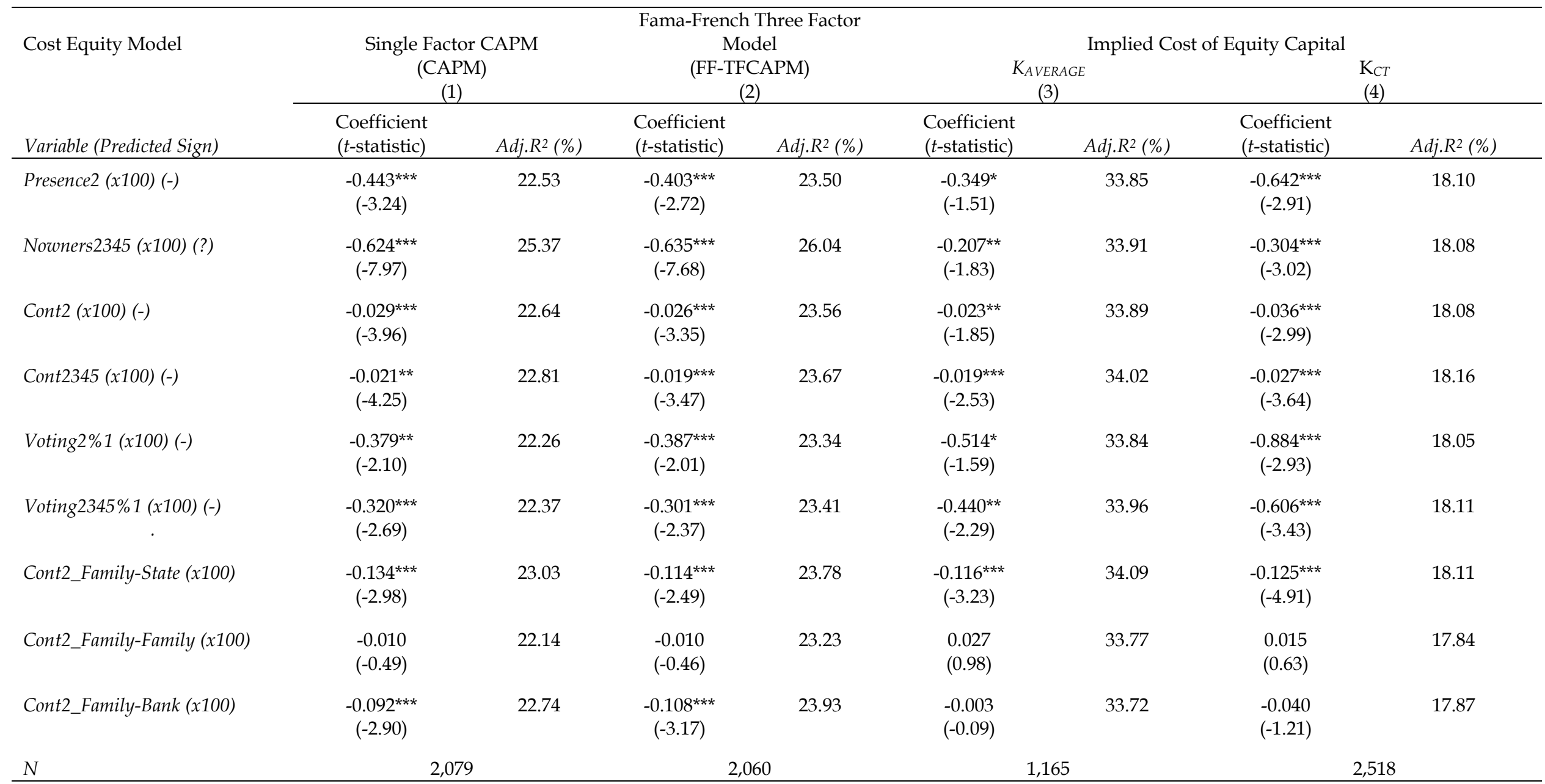

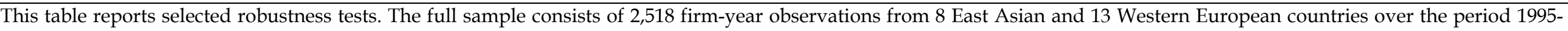

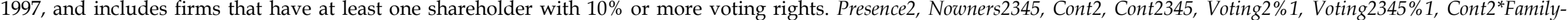

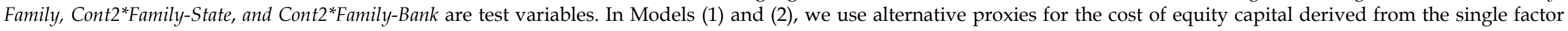

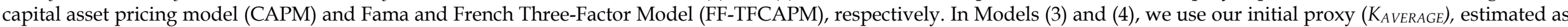

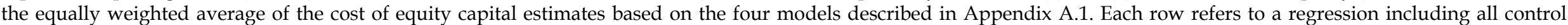

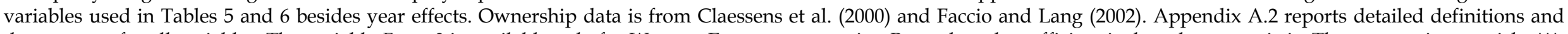

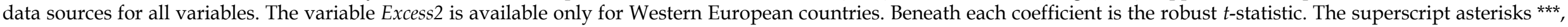
${ }^{* *},{ }^{*}$ denote statistical significance at the $1 \%, 5 \%$, and $10 \%$ levels, respectively; one-tailed when directional predictions are made, and two-tailed otherwise. 
Table 9

Sensitivity Tests 2

\begin{tabular}{|c|c|c|c|c|c|c|c|c|c|c|c|c|}
\hline Variable (Predicted Sign) & $\begin{array}{c}\text { Country } \\
\text { Ratings } \\
(1) \\
\end{array}$ & $\begin{array}{c}\text { Country } \\
\text { Ratings } \\
(2) \\
\end{array}$ & $\begin{array}{c}\text { Forecast } \\
\text { Bias } \\
(3) \\
\end{array}$ & $\begin{array}{c}\text { Forecast } \\
\text { Bias } \\
(4) \\
\end{array}$ & $\begin{array}{c}\text { Excess1 } \\
>0 \\
(5)\end{array}$ & $\begin{array}{c}\text { Excess1 } \\
>0 \\
(6) \\
\end{array}$ & $\begin{array}{c}\text { Excess1 } \\
>10 \% \\
(7) \\
\end{array}$ & $\begin{array}{c}\text { Excess } 1 \\
>10 \% \\
(8) \\
\end{array}$ & $\begin{array}{c}0<\text { Excess } 1<=10 \% \\
(9)\end{array}$ & $\begin{array}{c}0<\text { Excess } 1<=10 \% \\
(10)\end{array}$ & $\begin{array}{c}\text { Excess1 \& } \\
\text { Excess2>0 } \\
(11) \\
\end{array}$ & $\begin{array}{c}\text { Excess1 \& } \\
\text { Excess2>0 } \\
(12)\end{array}$ \\
\hline Intercept (?) & $\begin{array}{c}-0.052^{* * *} \\
(-5.81)\end{array}$ & $\begin{array}{c}-0.032^{* * *} \\
(-3.61)\end{array}$ & $\begin{array}{l}0.011 \\
(1.38)\end{array}$ & $\begin{array}{l}0.011 \\
(1.30)\end{array}$ & $\begin{array}{l}0.024^{*} \\
(1.81)\end{array}$ & $\begin{array}{c}0.027^{* *} \\
(1.99)\end{array}$ & $\begin{array}{c}0.055^{* * *} \\
(2.74)\end{array}$ & $\begin{array}{c}0.055^{* * *} \\
(2.67)\end{array}$ & $\begin{array}{l}-0.011 \\
(-0.63)\end{array}$ & $\begin{array}{l}-0.007 \\
(-0.42)\end{array}$ & $\begin{array}{l}0.015 \\
(0.73)\end{array}$ & $\begin{array}{l}0.019 \\
(0.92)\end{array}$ \\
\hline Excess1 $(x 100)(+)$ & $\begin{array}{l}0.023^{* *} \\
(2.00)\end{array}$ & $\begin{array}{l}0.023^{* *} \\
(1.99)\end{array}$ & $\begin{array}{l}0.019^{* *} \\
(1.67)\end{array}$ & $\begin{array}{l}0.019^{* *} \\
(1.66)\end{array}$ & $\begin{array}{c}0.040^{* * *} \\
(2.55)\end{array}$ & $\begin{array}{c}0.042^{* * *} \\
(2.73)\end{array}$ & $\begin{array}{c}0.044^{* *} \\
(2.10)\end{array}$ & $\begin{array}{c}0.047^{* *} \\
(2.26)\end{array}$ & $\begin{array}{c}0.135^{* * *} \\
(2.57)\end{array}$ & $\begin{array}{c}0.131^{* * *} \\
(2.43)\end{array}$ & $\begin{array}{l}0.002 \\
(0.06)\end{array}$ & $\begin{array}{l}0.006 \\
(0.21)\end{array}$ \\
\hline Presence2 (x100) (-) & $\begin{array}{c}-0.556^{* * *} \\
(-3.34)\end{array}$ & & $\begin{array}{c}-0.425^{* * *} \\
(-2.51)\end{array}$ & & & & & & & & & \\
\hline Voting $2 \% 1(x 100)(-)$ & & $\begin{array}{c}-0.543^{* * *} \\
(-2.35)\end{array}$ & & $\begin{array}{c}-0.493^{* *} \\
(-2.09)\end{array}$ & & & & & & & & \\
\hline Cont2 (x100) (-) & & & & & $\begin{array}{c}-0.028^{* *} \\
(-1.66)\end{array}$ & $\begin{array}{c}-0.049^{* * *} \\
(-2.94)\end{array}$ & $\begin{array}{l}-0.036^{*} \\
(-1.55)\end{array}$ & $\begin{array}{c}-0.067^{* * * *} \\
(-2.90)\end{array}$ & $\begin{array}{l}-0.006 \\
(-0.26)\end{array}$ & $\begin{array}{l}-0.023 \\
(-0.91)\end{array}$ & $\begin{array}{c}-0.066^{* *} \\
(-2.05)\end{array}$ & $\begin{array}{c}-0.092^{* * *} \\
(-2.83)\end{array}$ \\
\hline Cont $2 *$ Family-State $x 100(+)$ & & & & & $\begin{array}{c}-0.114^{* * *} \\
(-4.30)\end{array}$ & & $\begin{array}{c}-0.192^{* * *} \\
(-3.94)\end{array}$ & & $\begin{array}{c}-0.120^{* * *} \\
(-3.43)\end{array}$ & & $\begin{array}{c}-0.111^{* * *} \\
(-4.27)\end{array}$ & \\
\hline Cont $2 *$ Family-Family $x 100(+)$ & & & & & & $\begin{array}{c}0.096^{* * *} \\
(2.64)\end{array}$ & & $\begin{array}{c}0.156^{* * *} \\
(3.58)\end{array}$ & & $\begin{array}{l}0.017 \\
(0.27)\end{array}$ & & $\begin{array}{c}0.092^{* * *} \\
(2.54)\end{array}$ \\
\hline Analyst Coverage $(x 10)(-)$ & $\begin{array}{c}-0.012^{* * *} \\
(-10.21)\end{array}$ & $\begin{array}{c}-0.012^{* * *} \\
(-10.23)\end{array}$ & $\begin{array}{c}-0.010^{* * *} \\
(-8.84)\end{array}$ & $\begin{array}{c}-0.010^{* * *} \\
(-8.88)\end{array}$ & $\begin{array}{c}-0.013^{* * *} \\
(-8.02)\end{array}$ & $\begin{array}{c}-0.013^{* * *} \\
(-8.45)\end{array}$ & $\begin{array}{c}-0.010^{* * *} \\
(-4.44)\end{array}$ & $\begin{array}{c}-0.011^{* * *} \\
(-4.75)\end{array}$ & $\begin{array}{c}-0.014^{* * *} \\
(-6.66)\end{array}$ & $\begin{array}{c}-0.015^{* * *} \\
(-7.05)\end{array}$ & $\begin{array}{c}-0.013^{* * *} \\
(-5.40)\end{array}$ & $\begin{array}{c}-0.013^{* * *} \\
(-5.86)\end{array}$ \\
\hline Market to Book (x10) (-) & $\begin{array}{c}-0.009^{* *} \\
(-2.29)\end{array}$ & $\begin{array}{c}-0.009^{* *} \\
(-2.27)\end{array}$ & $\begin{array}{c}-0.011^{* * *} \\
(-2.49)\end{array}$ & $\begin{array}{c}-0.011^{* * *} \\
(-2.48)\end{array}$ & $\begin{array}{c}-0.006^{* *} \\
(-1.83)\end{array}$ & $\begin{array}{c}-0.006^{* *} \\
(-1.83)\end{array}$ & $\begin{array}{c}-0.054^{* * *} \\
(-5.25)\end{array}$ & $\begin{array}{c}-0.052^{* * *} \\
(-5.17)\end{array}$ & $\begin{array}{c}-0.004^{* *} \\
(-1.98)\end{array}$ & $\begin{array}{c}-0.004^{* *} \\
(-1.93)\end{array}$ & $\begin{array}{c}-0.068^{* * *} \\
(-5.83)\end{array}$ & $\begin{array}{c}-0.069^{* * *} \\
(-5.74)\end{array}$ \\
\hline Variance of Analyst Forecasts (+) & $\begin{array}{c}0.023^{* * *} \\
(5.19)\end{array}$ & $\begin{array}{c}0.024^{* * *} \\
(5.24)\end{array}$ & $\begin{array}{c}0.022^{* * *} \\
(5.14)\end{array}$ & $\begin{array}{c}0.022^{* * *} \\
(5.17)\end{array}$ & $\begin{array}{l}0.014^{* *} \\
(2.32)\end{array}$ & $\begin{array}{c}0.015^{* * *} \\
(2.34)\end{array}$ & $\begin{array}{l}0.017 \\
(1.08)\end{array}$ & $\begin{array}{l}0.018 \\
(1.10)\end{array}$ & $\begin{array}{c}0.012^{* * *} \\
(2.38)\end{array}$ & $\begin{array}{c}0.012^{* * *} \\
(2.43)\end{array}$ & $\begin{array}{l}0.018^{*} \\
(1.55)\end{array}$ & $\begin{array}{l}0.019^{*} \\
(1.59)\end{array}$ \\
\hline Volatility (+) & $\begin{array}{c}0.013^{* * *} \\
(2.87)\end{array}$ & $\begin{array}{c}0.012^{* * *} \\
(2.78)\end{array}$ & $\begin{array}{c}0.027^{* * *} \\
(6.06)\end{array}$ & $\begin{array}{c}0.027^{* * *} \\
(5.95)\end{array}$ & $\begin{array}{c}0.028^{* * *} \\
(3.21)\end{array}$ & $\begin{array}{c}0.027^{* * *} \\
(3.12)\end{array}$ & $\begin{array}{c}0.035^{* * *} \\
(2.51)\end{array}$ & $\begin{array}{c}0.032^{* * *} \\
(2.40)\end{array}$ & $\begin{array}{c}0.026^{* * *} \\
(2.47)\end{array}$ & $\begin{array}{c}0.026^{* * *} \\
(2.45)\end{array}$ & $\begin{array}{c}0.036^{* * *} \\
(3.00)\end{array}$ & $\begin{array}{c}0.034^{* * *} \\
(2.93)\end{array}$ \\
\hline Leverage $(x 100)(+)$ & $\begin{array}{c}0.014^{* * *} \\
(3.44)\end{array}$ & $\begin{array}{c}0.014^{* * *} \\
(3.45)\end{array}$ & $\begin{array}{c}0.016^{* * *} \\
(3.84)\end{array}$ & $\begin{array}{c}0.016^{* * *} \\
(3.85)\end{array}$ & $\begin{array}{c}0.025^{* * *} \\
(3.46)\end{array}$ & $\begin{array}{c}0.025^{* * *} \\
(3.46)\end{array}$ & $\begin{array}{l}-0.001 \\
(-0.07)\end{array}$ & $\begin{array}{l}0.004 \\
(0.46)\end{array}$ & $\begin{array}{c}0.034^{* * *} \\
(3.32)\end{array}$ & $\begin{array}{c}0.032^{* * *} \\
(3.11)\end{array}$ & $\begin{array}{l}0.007 \\
(0.75)\end{array}$ & $\begin{array}{l}0.007 \\
(0.72)\end{array}$ \\
\hline Growth (+) & $\begin{array}{l}0.028^{* *} \\
(2.12)\end{array}$ & $\begin{array}{l}0.028^{* *} \\
(2.12)\end{array}$ & $\begin{array}{l}0.028^{* *} \\
(2.00)\end{array}$ & $\begin{array}{c}0.028^{* *} \\
(2.01)\end{array}$ & $\begin{array}{c}0.088^{* * *} \\
(5.48)\end{array}$ & $\begin{array}{c}0.090^{* * *} \\
(5.61)\end{array}$ & $\begin{array}{c}0.080^{* * *} \\
(2.73)\end{array}$ & $\begin{array}{c}0.081^{* * *} \\
(2.80)\end{array}$ & $\begin{array}{c}0.104^{* * *} \\
(5.39)\end{array}$ & $\begin{array}{c}0.106^{* * *} \\
(5.45)\end{array}$ & $\begin{array}{c}0.090^{* * *} \\
(4.07)\end{array}$ & $\begin{array}{c}0.093^{* * *} \\
(4.16)\end{array}$ \\
\hline Industry Cost of Capital (+) & $\begin{array}{c}0.880^{* * *} \\
(14.19)\end{array}$ & $\begin{array}{c}0.884^{* * *} \\
(14.28)\end{array}$ & $\begin{array}{c}0.915^{* * *} \\
(14.07)\end{array}$ & $\begin{array}{c}0.917^{* * *} \\
(14.13)\end{array}$ & $\begin{array}{c}0.733^{* * *} \\
(7.18)\end{array}$ & $\begin{array}{c}0.716^{* * *} \\
(6.96)\end{array}$ & $\begin{array}{c}0.472^{* * *} \\
(3.20)\end{array}$ & $\begin{array}{c}0.465^{* * *} \\
(3.06)\end{array}$ & $\begin{array}{c}0.934^{* * *} \\
(7.20)\end{array}$ & $\begin{array}{c}0.914^{* * *} \\
(7.02)\end{array}$ & $\begin{array}{c}0.842^{* * *} \\
(5.73)\end{array}$ & $\begin{array}{c}0.817^{* * *} \\
(5.36)\end{array}$ \\
\hline Ln(100-Country Ratings) (+) & $\begin{array}{c}0.019^{* * *} \\
(11.52)\end{array}$ & $\begin{array}{c}0.019^{* * *} \\
(11.37)\end{array}$ & & & & & & & & & & \\
\hline Forecast Bias x100 (+) & & & $\begin{array}{c}0.042^{* * *} \\
(4.02)\end{array}$ & $\begin{array}{c}0.042^{* * *} \\
(3.92)\end{array}$ & & & & & & & & \\
\hline Year Effects & Yes & Yes & Yes & Yes & Yes & Yes & Yes & Yes & Yes & Yes & Yes & Yes \\
\hline $\operatorname{Adj} . R^{2}(\%)$ & 30.9 & 30.7 & 27.1 & 27.0 & 33.7 & 33.7 & 32.3 & 32.9 & 40.9 & 40.3 & 40.8 & 40.7 \\
\hline$N$ & 2,518 & 2,518 & 2,518 & 2,518 & 1,002 & 1,002 & 492 & 492 & 510 & 510 & 488 & 488 \\
\hline
\end{tabular}




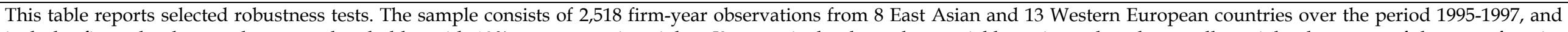

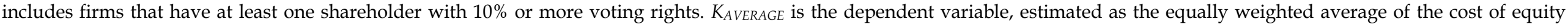

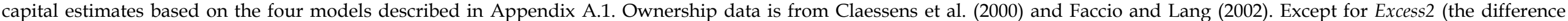

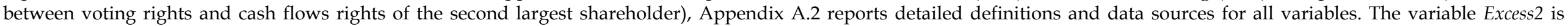

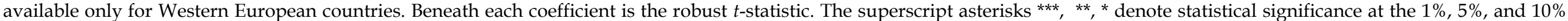
levels, respectively; one-tailed when directional predictions are made, and two-tailed otherwise. 